\title{
Dynamics of Housing Price: Foreclosure Rate Interactions
}

\author{
John F. McDonald and Houston H. Stokes \\ Department of Economics, University of Illinois at Chicago, Chicago, IL 60680, USA \\ Correspondence should be addressed to John F. McDonald; mcdonald@uic.edu
}

Received 6 August 2013; Accepted 10 September 2013

Academic Editors: D. M. Hanink, A. Rodriguez-Alvarez, and B. M. Tabak

Copyright ( 2013 J. F. McDonald and H. H. Stokes. This is an open access article distributed under the Creative Commons Attribution License, which permits unrestricted use, distribution, and reproduction in any medium, provided the original work is properly cited.

The dynamic impacts of the federal funds rate and the foreclosure rate on the log of the S\&P/Case-Shiller aggregate 10-city monthly housing price index are investigated using VMA modeling techniques in the period 2000(1)-2011(3). The findings are consistent with the view that the interest rate policy of the Federal Reserve in that period that kept rates artificially low contributed to the housing bubble. Positive shocks in the foreclosure rate are shown to be associated with declines in the change in the housing price index after a lag. In addition, negative shocks in the change in the housing price index are associated with a higher foreclosure rate. The results suggest that both the change in the housing price index and the foreclosure rate create a negative externality that is dynamic.

\section{Introduction}

Recent studies have documented the negative impact of foreclosures on housing prices. The most recent studies employ data that pertain to the period after the collapse of the housing price bubble in the US. As this paper is being written, the effects of the boom and bust of housing prices are still playing out over seven years after the peak in housing prices. The research strategy that has been followed in most of the previous studies is to examine the effect of nearby foreclosures in a recent prior time period on the selling prices of individual houses. However, most of these studies do not examine the effect of a decline in housing prices on foreclosure rates (An exception is the recent study by Capozza and Van Order [1], which finds that worsening economic conditions (i.e., declining house prices) are associated with much of the increase in mortgage defaults.). It is generally understood that a drop in the value of a house increases the incentive to default of the mortgage loan, especially if the fall in house value puts the owner "under water." The remaining balance on the loan is greater than the value of the house. A foreclosed house adds one more house to the supply of houses but does not increase demand since the credit rating of the prior owners is usually lower, limiting their demand in the housing market. The net effect is a further downward pressure on housing prices, usually with a lag.
The basic hypothesis to be investigated in this paper is that house prices and foreclosure rates interact over time conditional on the log federal funds rate. The results of the study show that the housing market generates dynamic negative externalities that at this time seem to have no end point. An increase in foreclosures begets declines in house prices, which may lead to further increases in foreclosures and further declines in housing prices, and on and on. These effects may operate with complex time lags that differ across cities. Furthermore, housing prices react to lag housing prices (the bubble and crash phenomena), and the same may be true for foreclosures as well. Due to the dynamics of the relationship and the possibility of feedback, the study of these ideas requires the use of time-series data and timeseries econometric methods. It is not possible to detect these possible effects using cross-section analysis or annual data. As a result, this study employs monthly data for thirteen metropolitan areas on single-family housing prices and home mortgage foreclosure rates and builds on McDonald and Stokes [2] a time-series study of monetary policy and housing prices in those metropolitan areas over a longer period (Other recent studies of the impact of monetary policy on housing prices and other variables using time-series analysis include Jarociński and Smets [3] and Vargas-Silva [4]. Vargas-Silva provides a useful summary of previous studies of monetary 
policy and housing. However, these studies did not examine foreclosures.). Data for the US are also studied.

The general topic to which this paper contributes is of critical importance, and recent research has included special issues in major journals, such as Green et al. [6] and Sanders and Van Order [7]. This paper is the first to employ modern time-series methods to study the interactions between housing prices and foreclosure rates.

\section{Review of the Literature}

Four strands of housing literature are relevant to this study:

(i) research on mortgage default,

(ii) studies of the impact of mortgage default and foreclosure on the price of the house and losses suffered,

(iii) studies of the spillover effect of foreclosures on neighboring property selling prices,

(iv) studies of housing price dynamics (i.e., price bubbles).

Mortgage default is the topic of a great deal of research. Vandell [8] provided an early survey, and LaCour-Little [9] is a more recent survey article. Mortgage default is considered to be a function of (changes in) the borrower's ability to pay and/or the borrower's equity (the put option model). Deng et al. [10] show that negative equity is a necessary condition for default, but studies conducted prior to the financial crisis (Vandell [8] and Deng et al. [10]) show that negative equity is not enough to trigger default. Foote et al. [11] found that subprime loans with adjustable interest rates are sensitive to declining housing prices and Capozza and Van Order [1] found that declining economic conditions caused defaults. Research by Deng et al. [10] and others shows that shocks such as unemployment, divorce, and health problems are factors that lead to default, and Deng et al. [12] found that the desire to move when there is negative equity generates defaults. All of these forces have been at work in the financial crisis that began in 2007. The declines in housing prices that began in 2006 wiped out the equity of millions of home owners and put them "under water," and the resulting recession reduced their ability to pay and motivated households to move to rental housing. One lesson from the previous research is that a decline in housing prices alone does not necessarily lead to foreclosures. Indeed, it is now well documented by the Financial Crisis Inquiry Commission [13, page 217] and many others that foreclosures were concentrated among the subprime and adjustable-rate mortgages. As discussed below, most of these mortgages were structured to cause default if borrowers were unable to refinance after two or three years at more favorable terms. The recent study by deRitis et al. [14] finds that both "teaser" rate shocks and market rate shocks increased the mortgage delinquency, and Archer and Smith [15] find that the put option is an important factor in default.

The extensive literature on mortgage default and foreclosure on selling price includes Clauretie and Herzog [16], Shilling et al. [17], Forgey et al. [18], Hardin and Wolverton [19], Springer [20], Carroll et al. [21], Pennington-Cross [22], Clauretie and Daneshvary [23], and Campbell et al. [24].
These studies document the sizable price discount that can vary from $7 \%$ to $27 \%$, depending upon location. The details of the foreclosure process and the mortgage insurance contract matter. The price discount and loss suffered by the lender and/or mortgage insurer are larger in states with judicial foreclosure compared to states with power-of-sale foreclosure. Clauretie and Herzog [16] showed that losses for mortgage insurers are greater if the entire loss is covered by insurance (i.e., FHA insurance) compared to coinsurance contracts that are typical with private mortgage insurance. Losses generally are lower if the foreclosure process can be completed quickly. States with power-of-sale foreclosure, deficiency judgments permitted, and no statutory right of redemption have more expeditious foreclosures and smaller losses. Goodman and Smith [25] found lower default rates in states in which default is more costly to lenders. Mian et al. [26] find that while loan delinquency rates are similar, foreclosure rates are lower in states with judicial foreclosure procedures (rather than power-of-sale procedures) because costs of foreclosure are greater. Their findings are an important part of the puzzle but due to the fact that they use annual data and only two periods, 2008 and 2009, cannot because of research design effectively study the dynamics of adjustment that is the focus of our paper.

Studies of the spillover effect of foreclosures on the selling prices of neighboring properties are reviewed by Daneshvary et al. [27], and include Immergluck and Smith [28], Lin et al. [29], Schuetz et al. [30], Harding et al. [31], Leonard and Murdoch [32], Rogers and Winter [33], Campbell et al. [24], and Mian et al. [26]. With the exception of Campbell et al. [24], Daneshvary et al. [27], and Mian et al. [26], all of the previous studies were based on samples of sales of nondistressed houses during a time period of stability in the housing market. Except for Lin et al. [29], these studies found relatively small effects of $1 \%$ or less of one or more nearby foreclosed properties on the selling price of a non-distressed property. Lin et al. [29] found that a foreclosure within two years and 300 feet was associated with a price discount of $8.7 \%$. The time lag assumed between foreclosure and sale of the non-distressed property varied from study to study.

Daneshvary et al. [27] studied the spillover effect in Las Vegas during 2008, a year in which the number of distressed sales was extraordinarily large (Nevada uses a power-of-sale foreclosure process in which the foreclosure sale can take place three months after the notice of default has been issued by the lender to the property owner. There is no statutory right of redemption in Nevada (right of owner to regain the property after the foreclosure sale) and deficiency judgments are permitted-but not often sought.). During the 13 months covered by the study, there were a total of 22,532 sales of single-family houses, of which 7,017 were regular sales, 12,270 were sales of repossessed houses (REO sales), 2,185 were short sales, and 1,060 were sales of properties in the process of foreclosure (A short sale is a sale in which the lender agrees to permit the owner to arrange the sale of the property for less than the outstanding balance on the loan. This can be done either before or after the notice of default has been issued by the lender. A sale in process of foreclosure means that at the foreclosure sale that is conducted by the lender, a 
buyer other than the lender has purchased the property. The lender normally will bid the amount of the remaining loan balance plus costs. A basic distinction therefore is between a sale arranged by the owner (short sale) versus a sale conducted by the lender (sale in process of foreclosure or sale of REO property).). The study examines the spillover effects on non-distressed and distressed sales and controls for numerous features of the property, the neighborhood, and the general trend in housing prices. The results for the own-price discounts are that properties sold as short sales had a discount of about $9 \%$, while properties in the process of foreclosure or lender-owned (REO) properties were discounted about $15 \%$. These results are consistent with previous studies. The estimated spillover effects for sales of REO properties and properties in process of foreclosure are large and highly statistically significant. The estimated spillover effect of one such distressed sale is about $1 \%$ within 0.1 miles and three months after the transaction and increases with the number of these nearby distressed sales up to a maximum effect of about $8 \%$ at 20 distressed sales. Estimated spillover effects for such distressed sales within a six-month time window are about $20 \%$ lower than for the three-month window. However, no spillover effects of short sales were detected. Daneshvary et al. [27] conclude that short sales appear to be in the interest of the lender and in the public interest compared to sales that take place at the conclusion of the foreclosure process.

The large-scale study by Mian et al. [26] examined the effect of foreclosures on housing prices indices at the state, core based statistical area (CBSA), and zip code levels during 2007-2009 annual data. Mian et al. [26, page 2] began their study with the observation that a study seeking to estimate the effect of foreclosures on house prices is confounded by concerns of unobserved shocks and reverse causality. For example, an unobserved negative shock can drive down house prices and increase delinquencies and foreclosures at the same time.

Cross-section data on foreclosure rates, housing price indices, and other variables for this period are employed (Data on housing prices pertain to 2007-2009 or 2010q1, and foreclosure rate data pertain to 2008-2009.). Because the foreclosure rate and housing price data pertain approximately to the same time period and it is reasonable to presume that these two variables are simultaneously determined, an instrumental variable for the foreclosure rate was constructed. That instrumental variable is based on whether the state law requires a judicial foreclosure procedure. The study finds evidence that the contemporaneous foreclosure rate (i.e., within the same two-year time interval) has a large negative impact on housing prices at the state, CBSA, and zip code levels. The zip code samples are drawn from the border areas of two states that have different foreclosure procedure requirements-judicial versus power of sale. The study did not estimate the effect of housing prices on the foreclosure rate.

Evidence is accumulating in support of bubbles in the housing market. Shiller [34] believes that the housing price bubble in the US. began as early as 1997, while Zandi [35] dates the beginning of the bubble back to 2003. Econometric tests for the presence of asset price bubbles usually involve testing for a divorce of asset prices from fundamental determinants of value such as rent, real interest rates, risk premia, and changes in tax laws. A basic reference is Hamilton [36], who concluded that whether the data violate the hypothesis that value is function of fundamentals depends upon the validity of the restrictions assumed for the dynamics of those fundamentals. Recent econometric studies that find housing market bubbles include Mikhed and Zemćík [37], a study that finds breakdowns in the relationship between an index of housing prices and rent levels in 23 US metropolitan areas.

This brief review of the literature leads us to expect that foreclosures lead to declines in housing prices, and that there is momentum in housing prices. A decline in housing prices may lead to foreclosures, but this expectation is less certain unless combined with other factors that reduce the household's ability to pay debt service. The results of our study confirm that larger declines in housing prices are causally prior to higher foreclosure rates.

\section{The Data}

This study makes use of three monthly time-series data sets from January 1998 to March 2011: the S\&P/Case-Shiller Home Price Indices for 13 metropolitan areas, the foreclosure rate series provided by Zillow for these same metropolitan areas, and the federal funds rate. The Zillow foreclosure rate series is a weighted average of the current and past two months for the percentage of all homes foreclosed on in the given month (with the heaviest weight in the most recent month). Foreclosures include those sold at a sheriff's sale or forfeited to the bank. The metropolitan areas included in the study are Cleveland, Dallas, Denver, Las Vegas, Los Angeles, Minneapolis, New York, Phoenix, Portland, San Diego, San Francisco, Seattle, and Washington DC. These are the metropolitan areas for which both the S\&P/Case-Shiller and Zillow data are available. Graphical presentations of the home price indices and the federal funds rate are included in McDonald and Stokes study [2]. These graphs show that all thirteen metropolitan areas experienced home price declines beginning either in 2006 or 2007. The sharpest declines took place in Las Vegas, Los Angeles, Minneapolis, Phoenix, San Diego, and San Francisco, and the smallest decline occurred in Denver. The others fall somewhere in between. The federal funds rate increased from $4.07 \%$ to $6.60 \%$ in the period from 1998 to 2000 . The Federal Reserve lowered the rate to $1.54 \%$ in December 2001, and to $1.00 \%$ in August 2003. The rate was held at $1.00 \%$ till June 2004, and then began its steady rise to $5.25 \%$ in June 2006, where it remained until July 2007. The rate was dropped sharply in response to the financial crisis, reaching $0.10 \%$ in December 2008, and it remains at or below $0.20 \%$.

Data on log housing price index and the foreclosure rate for the US as a whole are shown in Figure 1. One issue is whether to use logs of the 10-city Case-Shiller series or the 20city Case-Shiller series. The left-hand plot in Exhibit 1 shows that both housing series move closely together, although the 10 -city series is in general somewhat higher. The middle plot shows the Case-Shiller 10-city series indexed on the left of the plot and the foreclosure rate indexed on the right of the plot. It is clear from the plot that there is a negative relationship 
Log Case-Shiller housing index and foreclosure rate US data
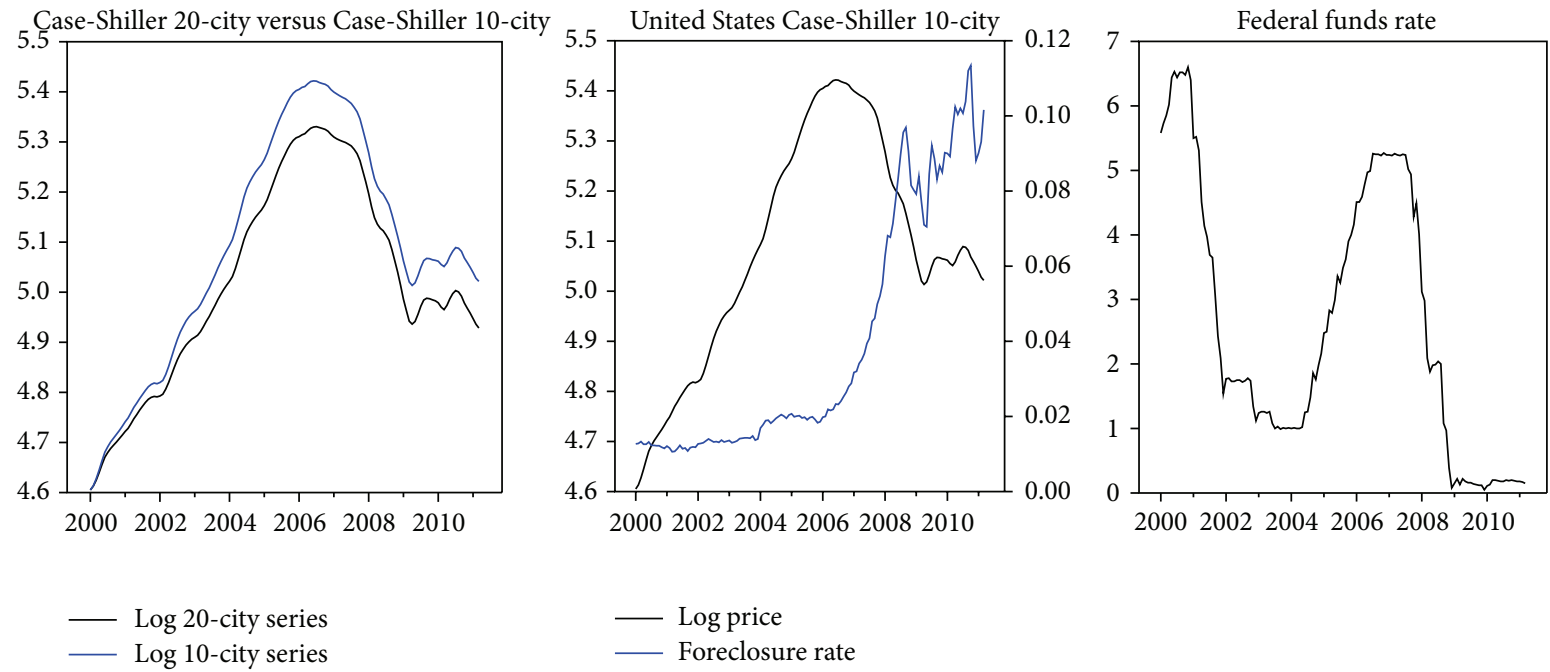

FIGURE 1

TABLE 1: Foreclosure systems.

\begin{tabular}{lccc}
\hline Metropolitan area & Method of foreclosure & Typical months to foreclosure sale & Statutory right of redemption \\
\hline Cleveland & Judicial & 8 & None \\
Dallas & Power of sale & 1 & None \\
Denver & Power of sale & 2 & 2.5 months \\
Las Vegas & Power of sale & 5 & None \\
Los Angeles & Power of sale & 5 & None \\
Minneapolis & Power of sale & 3 & 6 months \\
New York & Judicial & 8 & None \\
Phoenix & Power of sale & 4 & None \\
Portland & Power of sale & 9 & None \\
San Diego & Power of sale & 5 & None \\
San Francisco & Power of sale & 5 & None \\
Seattle & Power of sale & 1 & None \\
Washington DC & Power of sale & 2 & None \\
\hline
\end{tabular}

Source: Clauretie and Sirmans [5, p. 313].

between the two series after the peak of the housing series when the foreclosure rate started to pick up. What cannot be seen from the graph is the dynamics of the relationship between the two series.

While Figure 1 shows the national data, Figures 2 and 3 show the data for 13 cities. Cleveland, Las Vegas, New York, Los Angeles, Phoenix, Portland, Minneapolis, San Diego, Seattle, San Francisco, and Washington DC all follow the national pattern, except that the foreclosure rates in some of these metropolitan areas have declined somewhat from peak. Dallas, and to some extent Denver, did not experience a large decline in housing prices.

As noted above, the nature of the foreclosure process matters both for the propensity of foreclosures to occur and for the timing of any relationships between foreclosures and housing prices. Recent studies include Ghent and Kudlyak study [38], which examined the impact of deficiency judgments on defaults, and the Pennington-Cross [39] study of the effect of the statutory right of redemption. For these reasons, each metropolitan area is examined separately. The basic nature of the foreclosure process in each of these metropolitan areas is shown in Table 1.

Table 1 shows that the predominant method of foreclosure is power of sale, the procedure in which the lender can declare the borrower to be in default and schedule a foreclosure sale in accordance with the governing statute. Statutory right of redemption, in which the borrower has the opportunity to regain the property after the foreclosure sale, exists in only in two of the metropolitan areas.

Most of the foreclosure sales actually involve the lender assuming ownership (REO) rather than sheriff's sales. The foreclosure rate in any month is a small number; the overall 

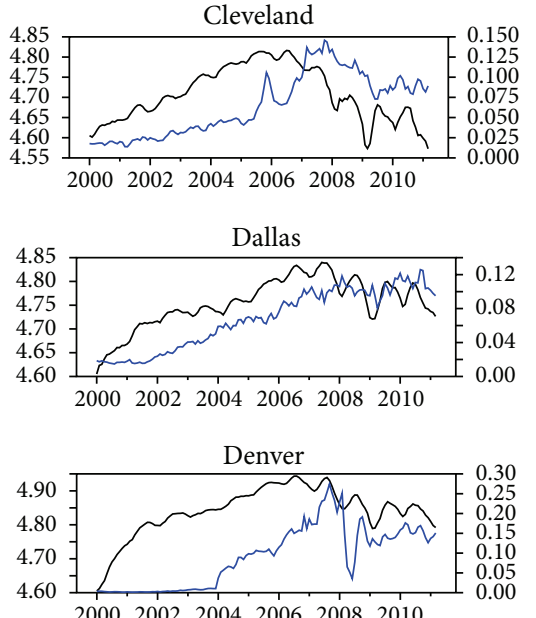

L_og price
Foreclosure rate
Log housing index versus foreclosure rate
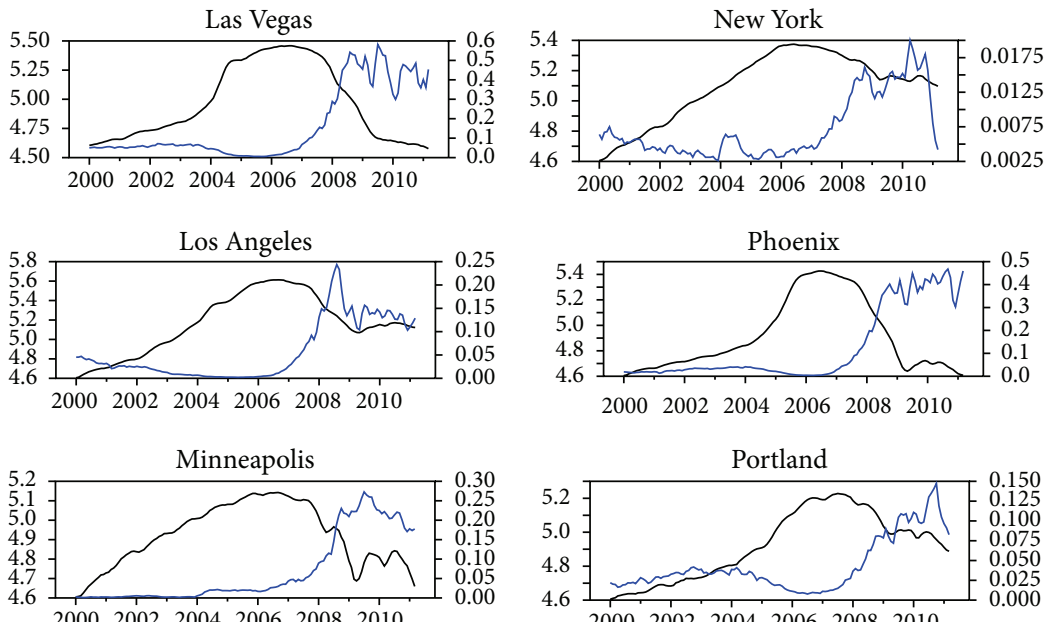

Log price
Foreclosure rate

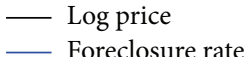

Figure 2

TABLE 2: Foreclosure Rates per Month: 2000 to 2011.

\begin{tabular}{|c|c|c|c|c|}
\hline Metropolitan Area & Mean & Standard Deviation & Minimum & Maximum \\
\hline Cleveland & $0.0577 \%$ & .0394 & $0.0128 \%$ & $0.1458 \%$ \\
\hline Dallas & 0.0609 & .0366 & 0.0147 & 0.1259 \\
\hline Denver & 0.0782 & .0771 & 0.0014 & 0.2745 \\
\hline Las Vegas & 0.1488 & .1759 & 0.0056 & 0.5815 \\
\hline Los Angeles & 0.0604 & .0582 & 0.0021 & 0.2437 \\
\hline Minneapolis & 0.0592 & .0845 & 0.0011 & 0.2727 \\
\hline New York & 0.0071 & .0043 & 0.0026 & 0.0200 \\
\hline Phoenix & 0.1132 & .1550 & 0.0038 & 0.4675 \\
\hline Portland & 0.0389 & .0335 & 0.0060 & 0.1473 \\
\hline San Diego & 0.0591 & .0767 & 0.0010 & 0.2976 \\
\hline San Francisco & 0.0511 & .0695 & 0.0024 & 0.2641 \\
\hline Seattle & 0.0353 & .0348 & 0.0092 & 0.1568 \\
\hline Washington, DC & 0.0397 & .0429 & 0.0029 & 0.1677 \\
\hline United States & 0.03621 & .03179 & .01060 & .11340 \\
\hline
\end{tabular}

Source: Zillow web site.

mean rate for the nation for the 1998-2011 period as recorded by Zillow is $0.0362 \%$ per month (with standard deviation of 0.03179 ). This foreclosure rate for the nation varies from a low rate of $0.0106 \%$ to a high rate of $0.1134 \%$ during these years. A summary of the foreclosure rate data for the 13 metropolitan areas is presented in Table 2.

Table 2 shows that the mean foreclosure rate varies from a low rate of $0.0071 \%$ in New York metropolitan area to a high rate of $0.1488 \%$ in the metropolitan area of Las Vegas. Metropolitan area of Phoenix has the next-highest mean foreclosure rate at $0.1132 \%$. Note that the mean foreclosure rates for the three California metropolitan areas are very similar at $0.05 \%$ to $0.06 \%$. Foreclosures in these three metropolitan areas are governed by the same state statute, of course. The figures for the minimum and maximum foreclosure rates demonstrate the great changes that took place as the financial crisis has proceeded. Foreclosure sales went from being a rarity (less than $0.015 \%$ per month) to a commonplace occurrence-as much as $0.5 \%$ per month in Las Vegas and Phoenix and $0.25 \%$ per month in Denver, Los Angeles, Minneapolis, San Diego, and San Francisco. The foreclosure rates in Denver, Las Vegas, Los Angeles, Minneapolis, Phoenix, San Diego, and San Francisco increased by factors that exceed 100. Metropolitan area of New York is the one place in which foreclosure sales never reached a relatively large number. The maximum is only $0.02 \%$.

\section{Model Estimation, Discussion, and Testing}

While the plots in Figures 1-3 are instructive, they do not allow us to measure the dynamic relationship between 
Log housing index versus foreclosure rate
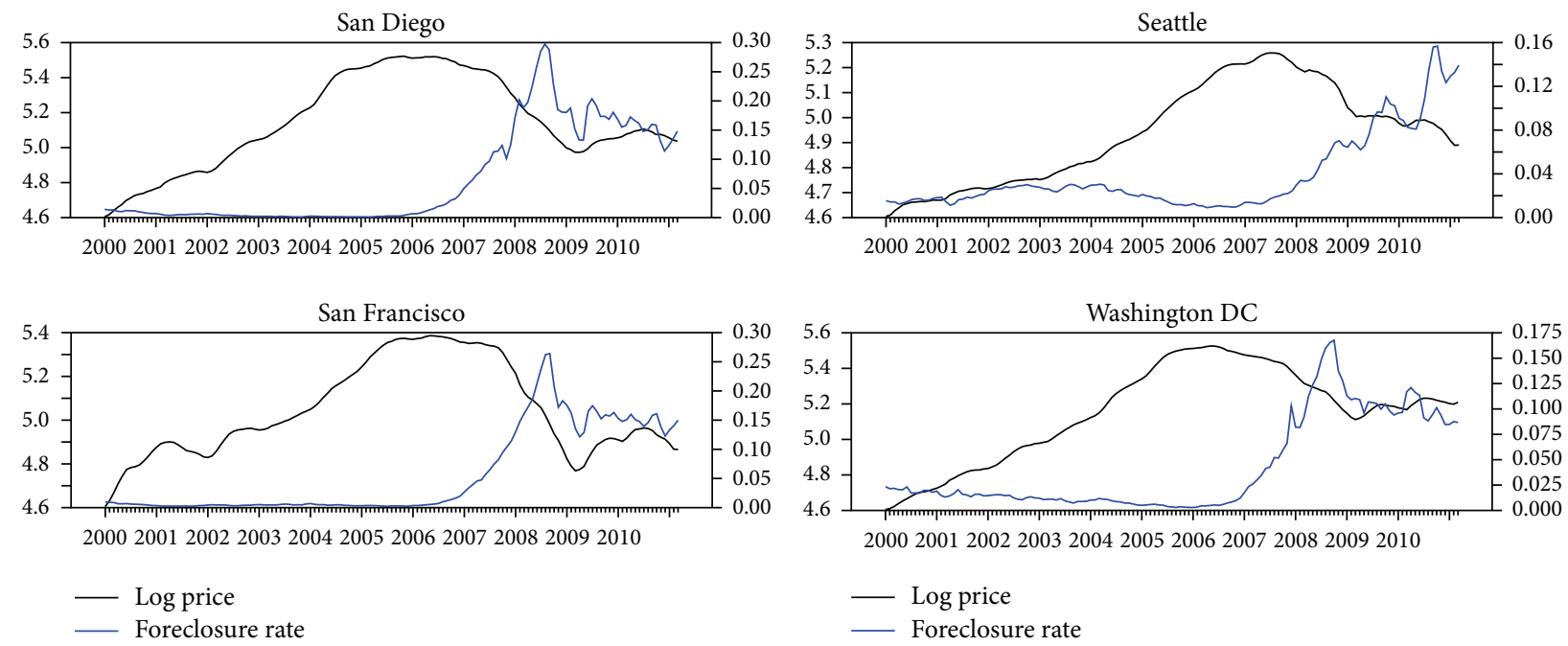

FIgURe 3

Impulse response functions for $\operatorname{dif}(\log )$ model for US

$2 \mathrm{SD}$ bounds set by Monte Carlo integration
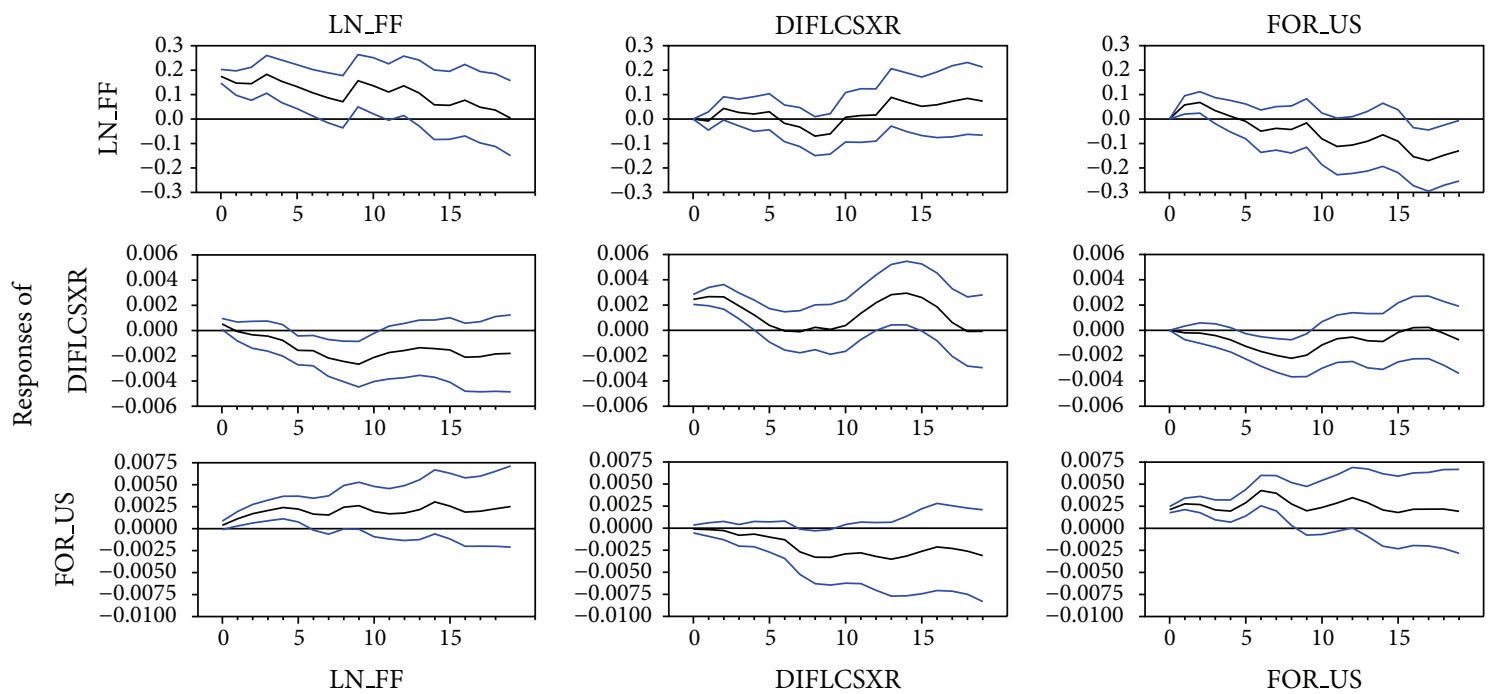

FIgURe 4

the three series. For this, we need a model. This section begins with a short discussion of one-way Granger causality but quickly moves on to the vector autoregressive model (VAR) that includes feedback effects and complex lag structures. The data used in this study are monthly time-series data that have been assembled to permit use of the VAR method.

Given that $y_{t}=$ the change in the log of composite housing price index in period $t, x_{1 t}=$ the log federal funds rate, and $x_{2 t}=$ the foreclosure rate, then $x_{j t}$ will Granger-cause $y_{t}$ [40] if a model

$$
y_{t}=a+\sum_{i=1}^{m} \gamma_{i} B^{i} y_{t}+\sum_{j=1}^{2} \sum_{i=1}^{m} \delta_{j i} B^{i} x_{j t}+e_{t}
$$

has a significantly lower error sum of squares than a model that restricts $\delta_{j i}=0$, for $i=1, \ldots, m$, where $B$ is the lag operator defined such as $B^{i} x_{j t} \equiv x_{j, t-i}$ as in Greene [41, page 699]. In order to use (1) to test for Granger causality, let the lag $m$ be set sufficiently long so as to remove all the significant autocorrelations in the error term $e_{t}$.

Given that housing prices and foreclosures are interrelated, the more satisfactory method is to use a VAR model that includes the possibility of feedback from $y$ to $x$ of the form

$$
\Phi(B)\left[\begin{array}{c}
x_{1 t} \\
x_{2 t} \\
y_{t}
\end{array}\right]=\left[\begin{array}{l}
e_{1 t} \\
e_{2 t} \\
e_{3 t}
\end{array}\right],
$$


Impulse response functions for $\operatorname{dif}(\log )$ model for Cleveland $2 \mathrm{SD}$ bounds set by Monte Carlo integration
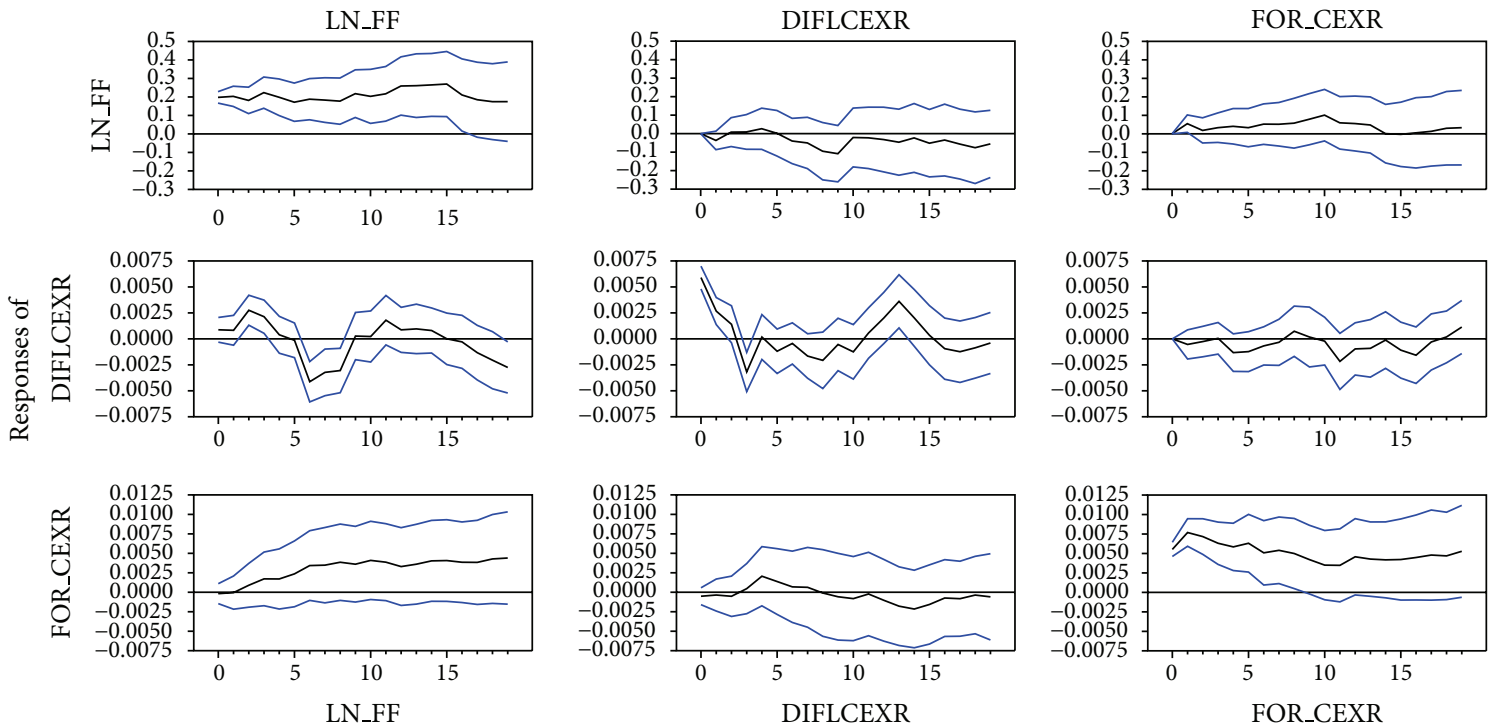

Figure 5

which can be written as

$$
\left[\begin{array}{llll}
\phi_{11}(B) & \phi_{12}(B) & \phi_{13}(B) \\
\phi_{21}(B) & \phi_{22}(B) & \phi_{23}(B) \\
\phi_{31}(B) & \phi_{32}(B) & \phi_{33}(B)
\end{array}\right]\left[\begin{array}{c}
x_{1 t} \\
x_{2 t} \\
y_{t}
\end{array}\right]=\left[\begin{array}{c}
e_{1 t} \\
e_{2 t} \\
e_{3 t}
\end{array}\right]
$$

where, for example, Granger causality from $x_{i t}$ to $y_{t}$ implies that $\phi_{3 i}(B) \neq 0$, where $\phi_{i j}(B)$ is a polynomial in the lag operator $B$ with $m$ terms. It should be noted that such a VAR model is a reduced form in which each dependent variable is a function of its own past values and past values of the other dependent variables. The empirical work in this paper is in the Sims [42] tradition. Zellner and Palm [43] have a detailed discussion of the relationship between these alternative models, both of which have their uses. For example, (1) can be written as

$$
\left(1-\sum_{i=1}^{m} \gamma_{i} B^{i}\right) y_{t}=a+\sum_{i=1}^{m} \delta_{1 i} B^{i} x_{1 t}+\sum_{i=1}^{m} \delta_{2 t} B^{i} x_{2 t}+e_{t},
$$

which can be simplified to

$$
\gamma(B) y_{t}=\delta_{1}(B) x_{1 t}+\delta_{2}(B) x_{2 t}+e_{t}
$$

Provided that $\gamma(B)$ is invertible $\left(\sum_{j=1}^{\infty}\left|\gamma_{i}\right|<\infty\right)$, (5) can be expressed as a rational distributed lag or transfer function, as in Box et al. [44]; that is,

$$
y_{t}=\frac{\delta_{1}(B)}{\gamma(B)} x_{1 t}+\frac{\delta_{2}(B)}{\gamma(B)} x_{2 t}+\frac{1}{\gamma(B)} e_{t} .
$$

The term $\delta_{i}(B) / \gamma(B)$ measures the effect of $x_{i t}$ on $y_{t}$ taking into account both the effect of lags of $x_{i t}$ on lags of $y_{t}$ and the direct effects of lags of $x_{i t}$ on $y_{t}$ and is called the impulse response function by Box et al. [44, page 13]. It is important to stress that (6) implies that there is no feedback from $y_{t}$ to $x_{i t}$ or that $\phi_{i j}(B) \equiv 0$ for $i<j$ in (3). Since McDonald and Stokes [2] found feedback from the log housing price, $y_{t}$, to the federal funds rate, $x_{1 t}$, the specification in (6) is not appropriate for the research design in this current paper that adds another variable, the foreclosure rate, to the analysis.

An alternative estimation approach that does not restrict feedback to zero by assumption is to invert the VAR model in (2) and form the vector moving average (VMA) form of the model which will allow measurement of shocks coming from one equation to impact another equation. A VAR model can be transformed to a VMA model, given $\Phi(B)$ is invertible, or

$$
\left[\begin{array}{c}
x_{1 t} \\
x_{2 t} \\
y_{t}
\end{array}\right]=\Theta(B)\left[\begin{array}{l}
e_{1 t} \\
e_{2 t} \\
e_{3 t}
\end{array}\right]
$$

where $\Theta(B) \equiv[\Phi(B)]^{-1}$. The terms in $\Theta(B)$ measure the dynamic responses of each of the potentially endogenous variables to shock the system. Equation (7) can be expanded to

$$
\left[\begin{array}{c}
x_{1 t} \\
x_{2 t} \\
y_{t}
\end{array}\right]=\left[\begin{array}{ccc}
\theta_{11}(B) & \theta_{12}(B) & \theta_{13}(B) \\
\theta_{21}(B) & \theta_{22}(B) & \theta_{23}(B) \\
\theta_{31}(B) & \theta_{32}(B) & \theta_{33}(B)
\end{array}\right]\left[\begin{array}{l}
e_{1 t} \\
e_{2 t} \\
e_{3 t}
\end{array}\right]
$$

Significance bounds on the VMA coefficients can be obtained using Monte Carlo integration (RATS software version 8.1 routine @mcgraphirf, Doan [44, page 495], is used to calculate using Monte Carlo integration the $95 \%$ bounds for $\theta_{i j}(B)$ for all nine possible cases. In general, the number of lags in VAR model $m$ is not the number of lags in $\theta_{i j}(B)$ which we will call $q$. In the results reported later, $m=12$ and $q=20$. The lag length $m$ was selected using both the $M$ statistic suggested by Tiao and Box as in [45] and inspection of 
Impulse response functions for $\operatorname{dif}(\log )$ model for Dallas

2 SD bounds set by Monte Carlo integration

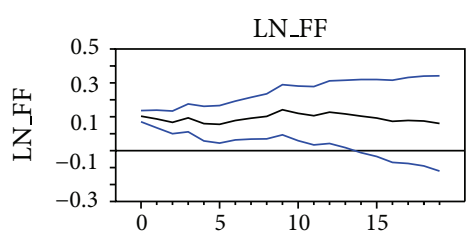

DIFLDAXR
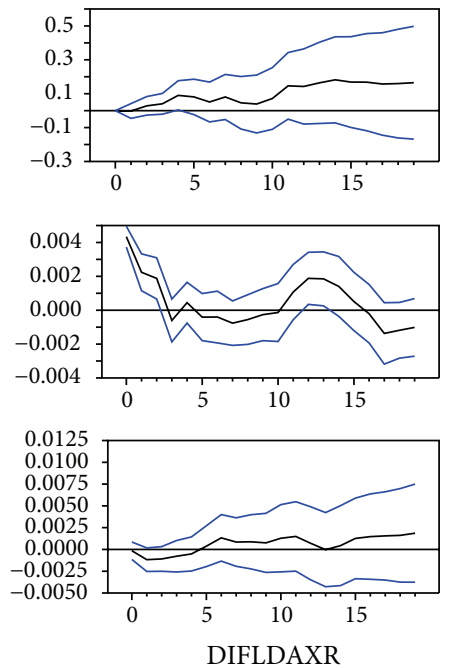

FIGURE 6

6
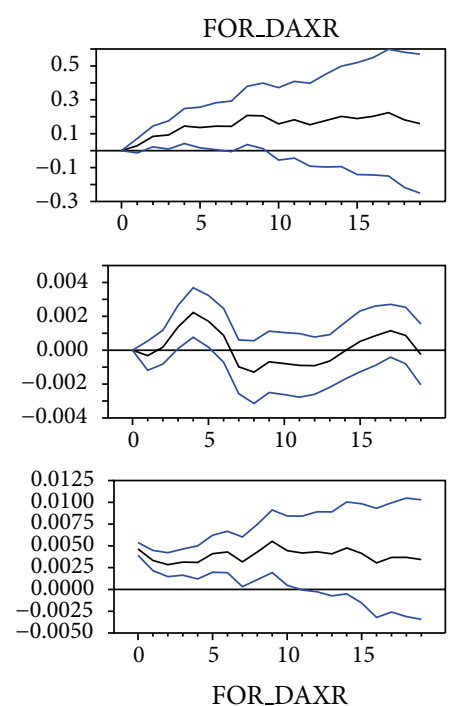

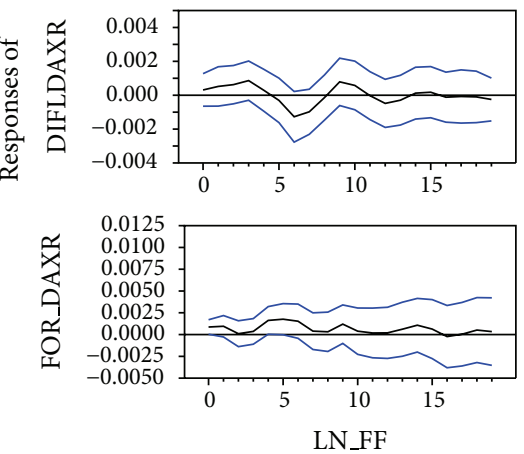

Impulse response functions for $\operatorname{dif}(\log )$ model for Denver

2 SD bounds set by Monte Carlo integration
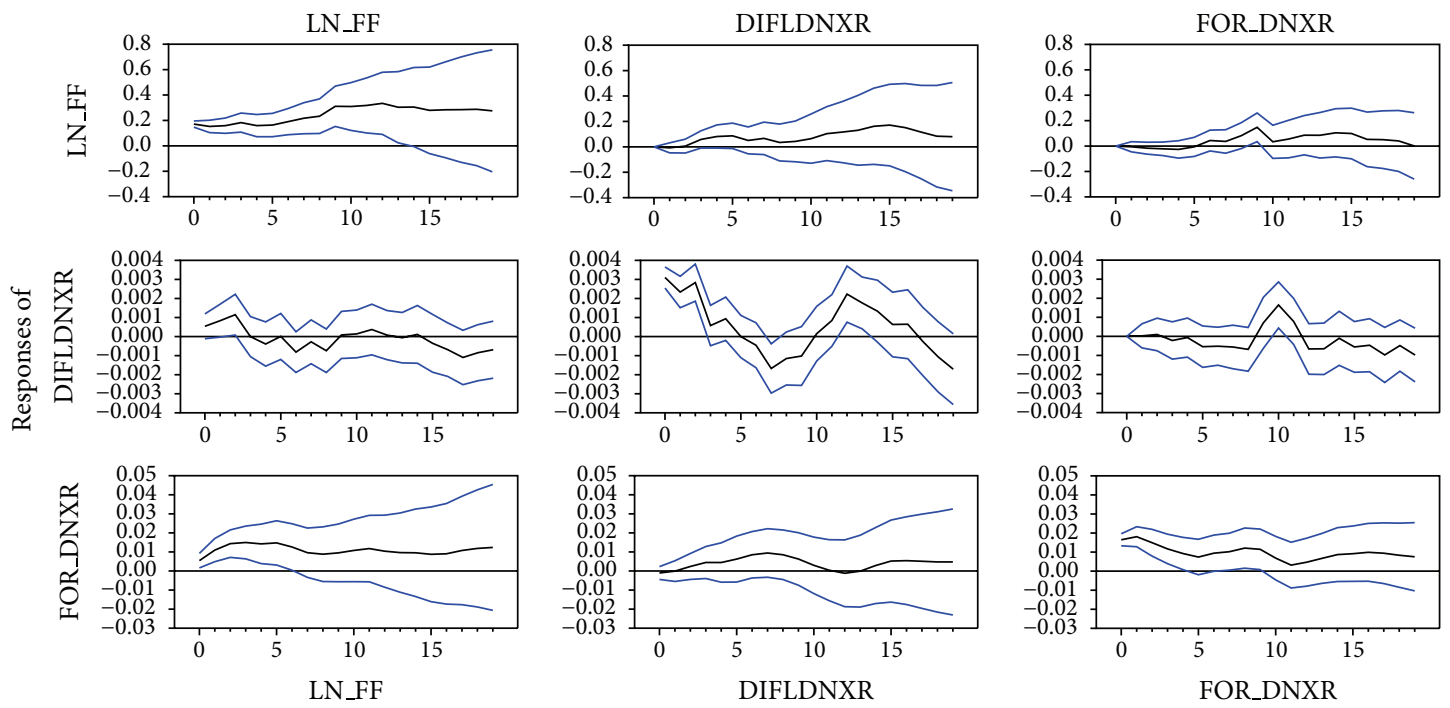

Figure 7

the cross-correlations. B34S version $8.11 \mathrm{~F}$ was used to calculate these tests reported in the paper. The results reported later are about the effects of normalized residuals.). The covariance matrix of the residuals $\Sigma$ is in general not diagonal since contemporaneous correlation between $x_{1 t}, x_{2 t}$, and $y_{t}$ cannot be ruled out. The effect of this possible endogeneity will be that the innovations $e_{1 t}, \ldots, e_{3 t}$ will not be orthogonal. The Cholesky factorization has been used to normalize the innovations using the lower triangular matrix $G$ defined such that $G \Sigma G^{\prime}=I$ which can be calculated as $G=F^{-1}$, where $F F^{\prime}=\Sigma$. $F$ and $G$ are lower triangular matrices. The new orthogonal innovations $\left[v_{1 t}, \ldots, v_{3 t}\right]^{\prime}=G\left[e_{1 t}, \ldots, e_{3 t}\right]^{\prime}$, however, are not invariant to the ordering of the series if there are contemporaneous effects resulting in $G$ not being diagonal. A finding that the results are substantially the same for different ordering of $x_{1 t}, x_{2 t}$, and $y_{t}$ is inconsistent with contemporaneous effects between the series.

If $x_{1 t}$ is the log of the federal funds rate, $x_{2 t}$ is the foreclosure rate, and $y_{t}$ is the change in the log of the housing price series, then the term $\theta_{31}(B)$ measures the effect of shocks in the log federal funds market on the log housing price variable, $\theta_{23}(B)$ measures the effect of shocks in the housing price series on the foreclosure rate, and $\theta_{32}(B)$ measures the effect of shocks in the foreclosure market on the log housing 
Impulse response functions for $\operatorname{dif}(\log )$ model for Las Vegas 2 SD bounds set by Monte Carlo integration
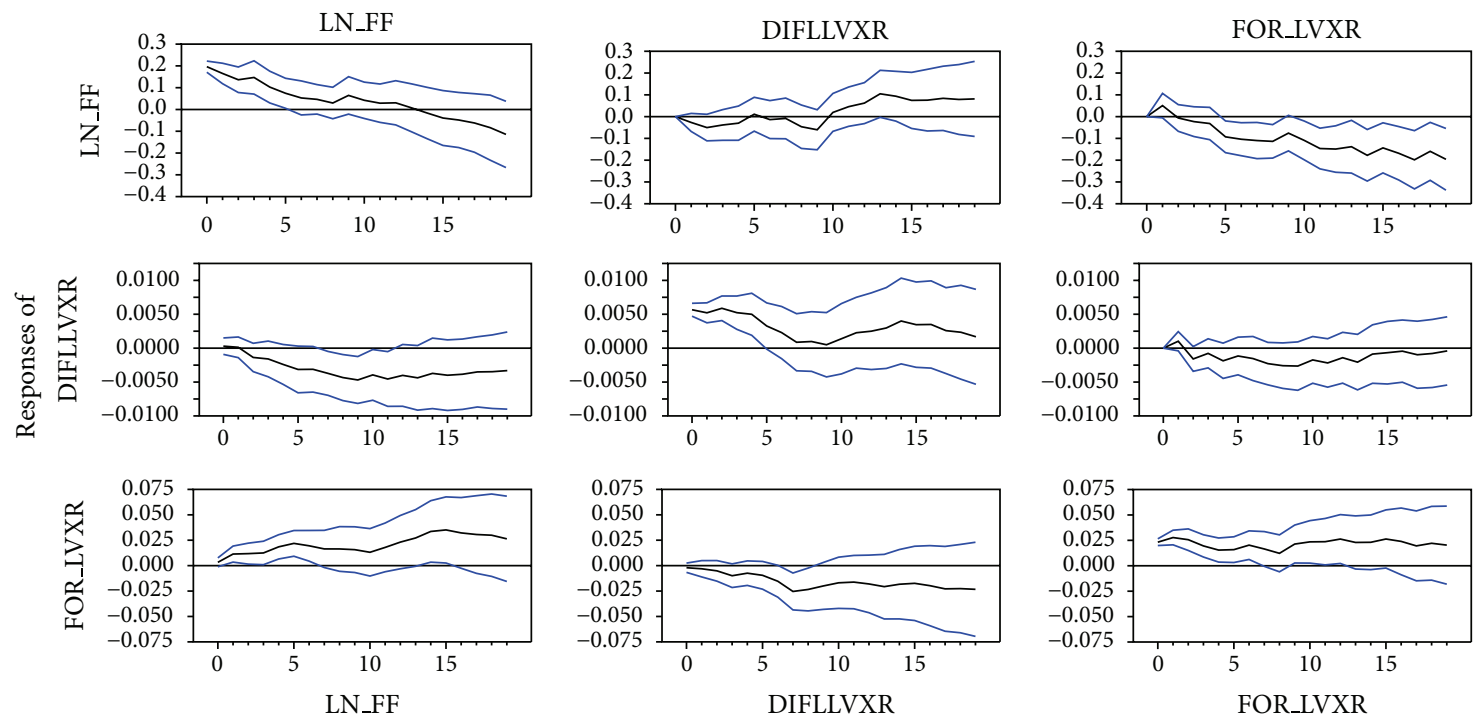

Figure 8

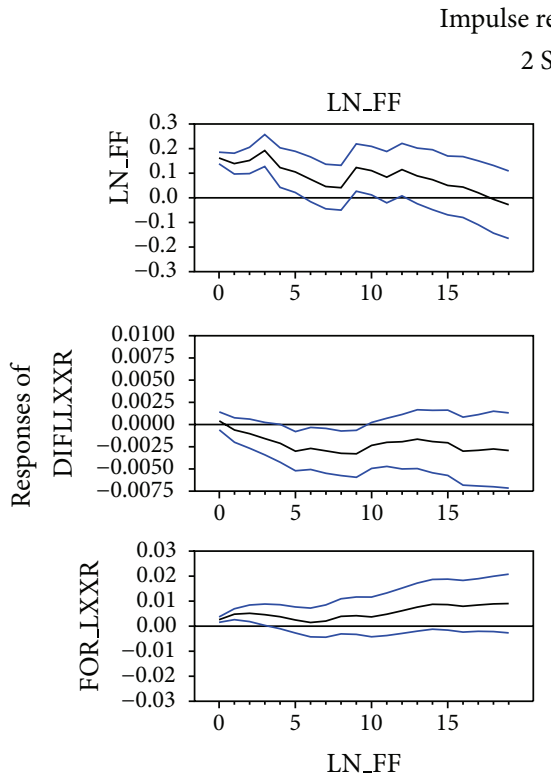

SD bounds set by Monte Carlo integration
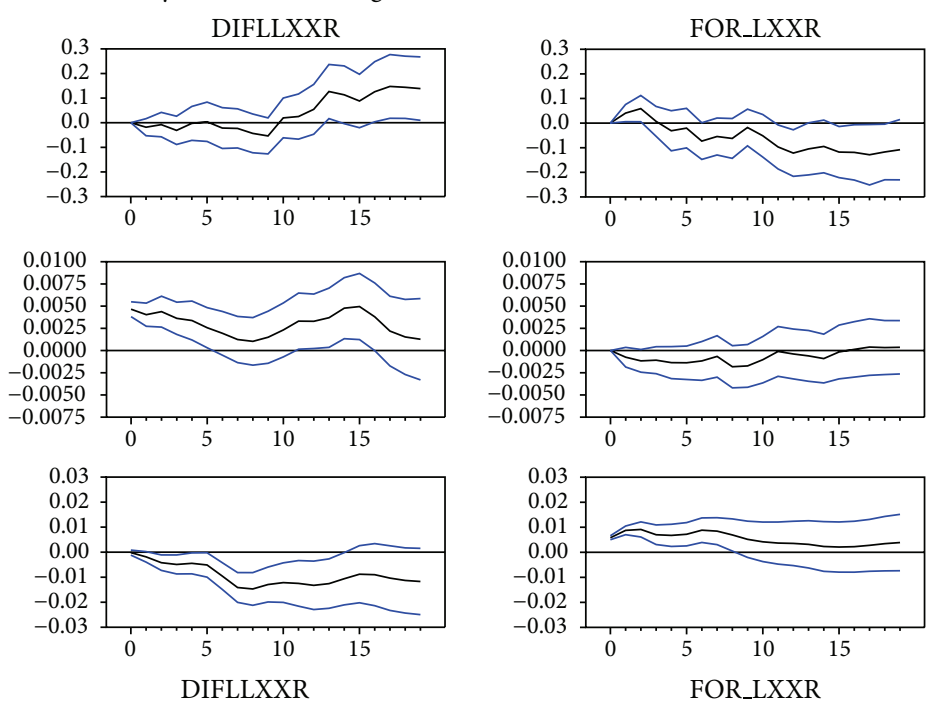

Figure 9

price variable. If $\theta_{i j}(B)=0$ for $i \neq j$, then each endogenous variable is not impacted from shocks coming from the other endogenous variables.

Theory would suggest that shocks from the interest side would have a negative effect on housing prices, resulting in $\theta_{31}(B)<0$, but positive shocks coming from the housing market would tend to have the Fed increase the federal funds rate, resulting in $\theta_{13}(B)>0$. Theory suggests both $\theta_{23}(B)$ and $\theta_{32}(B)<0$ : the housing price change variable and the foreclosure rate interact. These hypotheses will be investigated in the Results Section of this paper.

\section{Results}

The VAR model with three variables (natural log of federal funds rate, the foreclosure rate, and the change in the natural log of the house price index) was estimated for the US and for each of the 13 metropolitan areas using the software described by Stokes [46]. Interest centers on the interactions between two dependent variables, the foreclosure rate and the change in the log of the Case-Shiller housing price index. The best method for examining those interactions is to compute impulse response functions, which show 
Impulse response functions for $\operatorname{dif}(\log )$ model for Minneapolis 2 SD bounds set by Monte Carlo integration
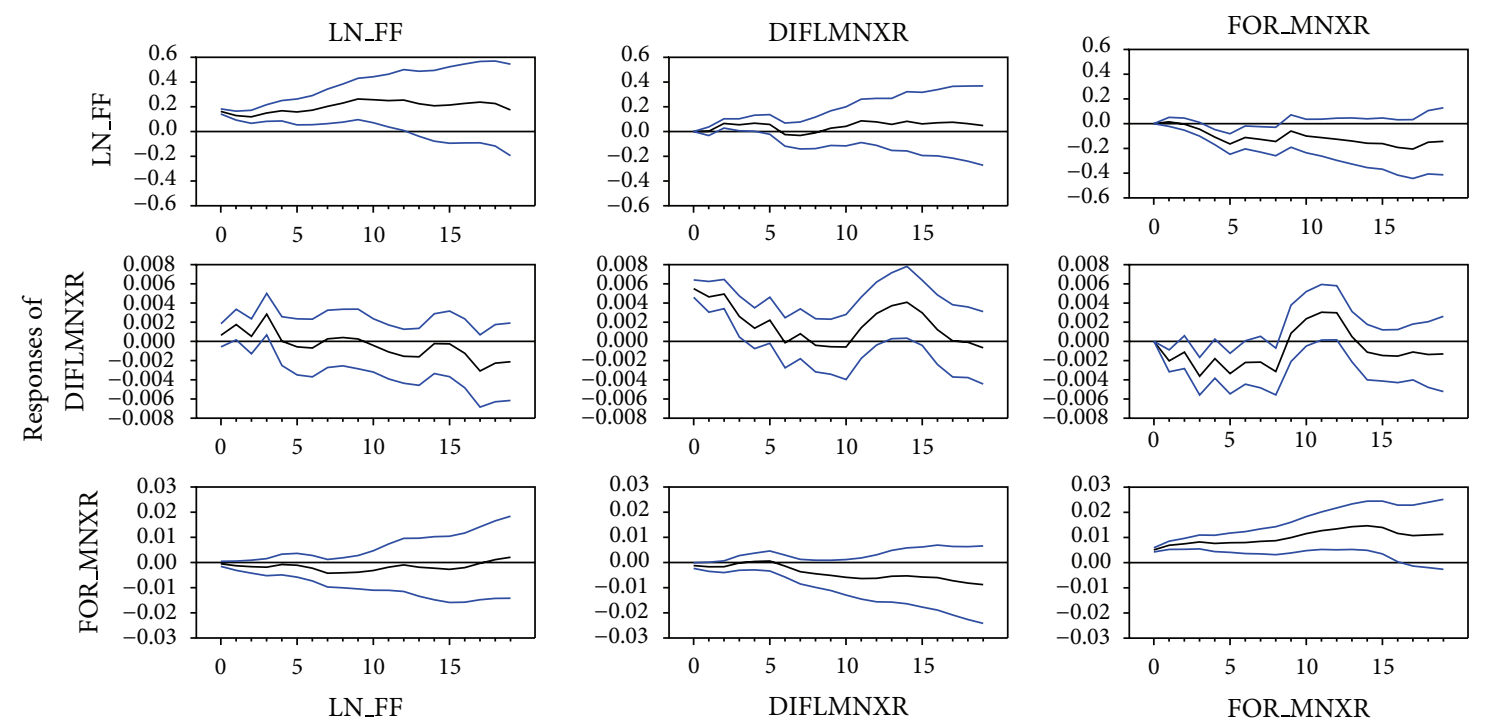

FIgURE 10

Impulse response functions for $\operatorname{dif}(\log )$ model for New York

2 SD bounds set by Monte Carlo integration
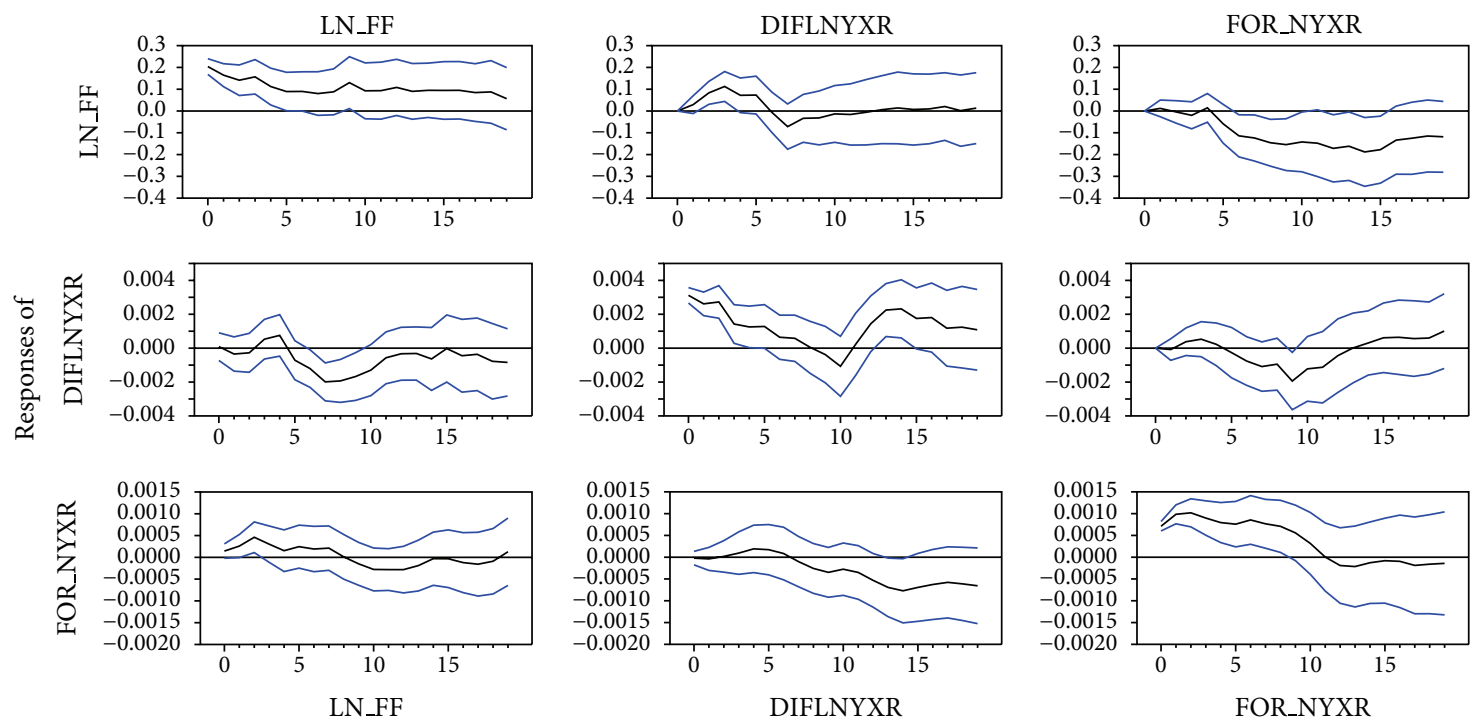

Figure 11

the computed distributions of the $\theta_{i j}$ terms from (8) based on 10,000 draws from the estimated distributions of error terms $e_{1 t}, e_{2 t}$, and $e_{3 t}$. The Monte Carlo procedure in RATS software version 8.1 , as explained by Doan $[45,47]$, is used to obtain estimates of the $95 \%$ confidence intervals for the effects of shocks in each of the three variables on equilibrium in the system. As discussed earlier, the Cholesky method was used to form orthogonal innovations. The lowest and highest $2.5 \%$ confidence intervals of the responses are excluded to produce the $95 \%$ confidence intervals. The results are presented in graphical form.
We hypothesized that the foreclosure rate might be interrelated with changes in the natural log of the housing price index. The change in the housing price index is generally positive prior to the peak and generally negative after the peak of the price bubble. Experts in time-series analysis such as Sims [42] and Enders [48, page 270] advise the researcher not to use the first differences in variables in VAR models because of the possibility that vital information will be discarded. However, in this case, the first difference in the housing price series provides vital information. When housing prices decline (increase), the foreclosure rate is apt 
Impulse response functions for $\operatorname{dif}(\log )$ model for Phoenix

$2 \mathrm{SD}$ bounds set by Monte Carlo integration
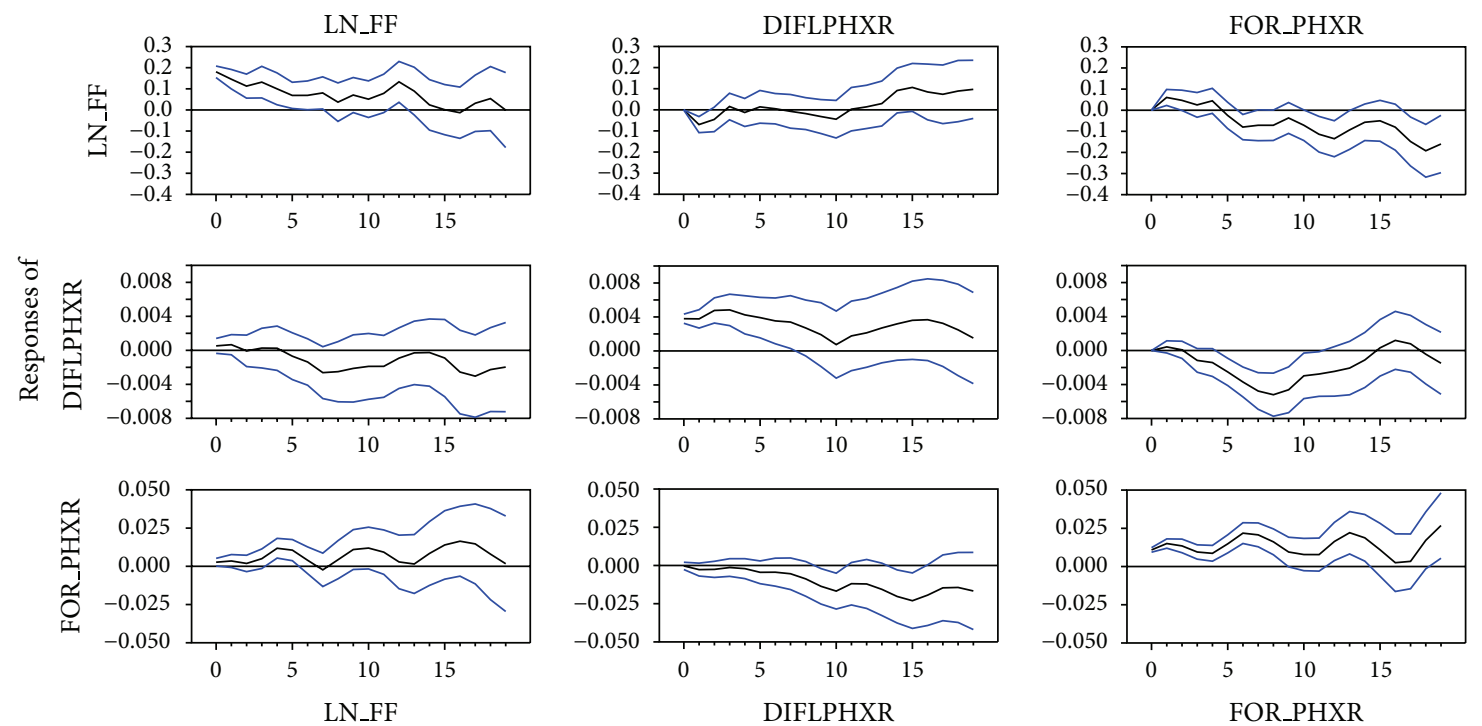

FIGURE 12

Impulse response functions for $\operatorname{dif}(\log )$ model for Portland

$2 \mathrm{SD}$ bounds set by Monte Carlo integration
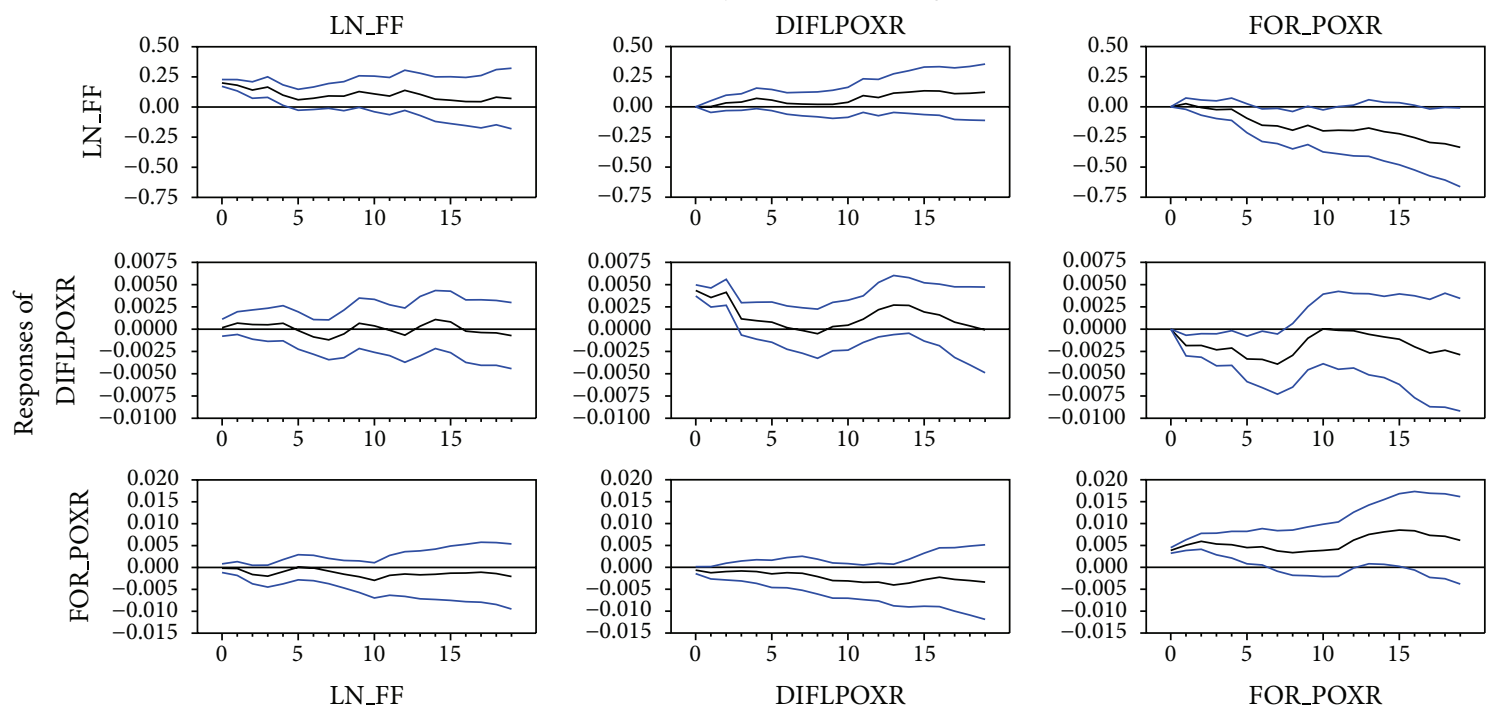

Figure 13

to rise (fall) because equity is lost (gained). And the larger the price decline the greater the loss in equity and the larger the foreclosure rate.

A summary of the impulse response function results is provided in Table 3. Graphs of the impulse response functions are shown in Figures 4, 5, 6, 7, 8, 9, 10, 11, 12, 13, 14, 15, 16, and 17. This table notes the instances in which six of the effects of shocks are different from zero with $95 \%$ confidence. Those six effects, together with their position (row and column) on the 3 by 3 graphs, are as follows:

(i) effect of the change in the natural log of house price $(\mathrm{LnP})$ index on foreclosure rate (Foreclose) in position $\theta_{23}(B)$, (ii) effect of foreclosure rate on the change in the natural $\log$ of house price in position $\theta_{32}(B)$,

(iii) effect of the change in the natural log of house price on itself in position $\theta_{33}(B)$,

(iv) effect of foreclosure rate on itself in position $\theta_{22}(B)$,

(v) effect of natural log of the federal funds rate (LnFF) on the change in the natural log of house price in position $\theta_{31}(B)$,

(vi) effect of natural log of the federal funds rate on foreclosure rate in position $\theta_{21}(B)$. 
Impulse response functions for $\operatorname{dif}(\log )$ model for San Diego

2 SD bounds set by Monte Carlo integration
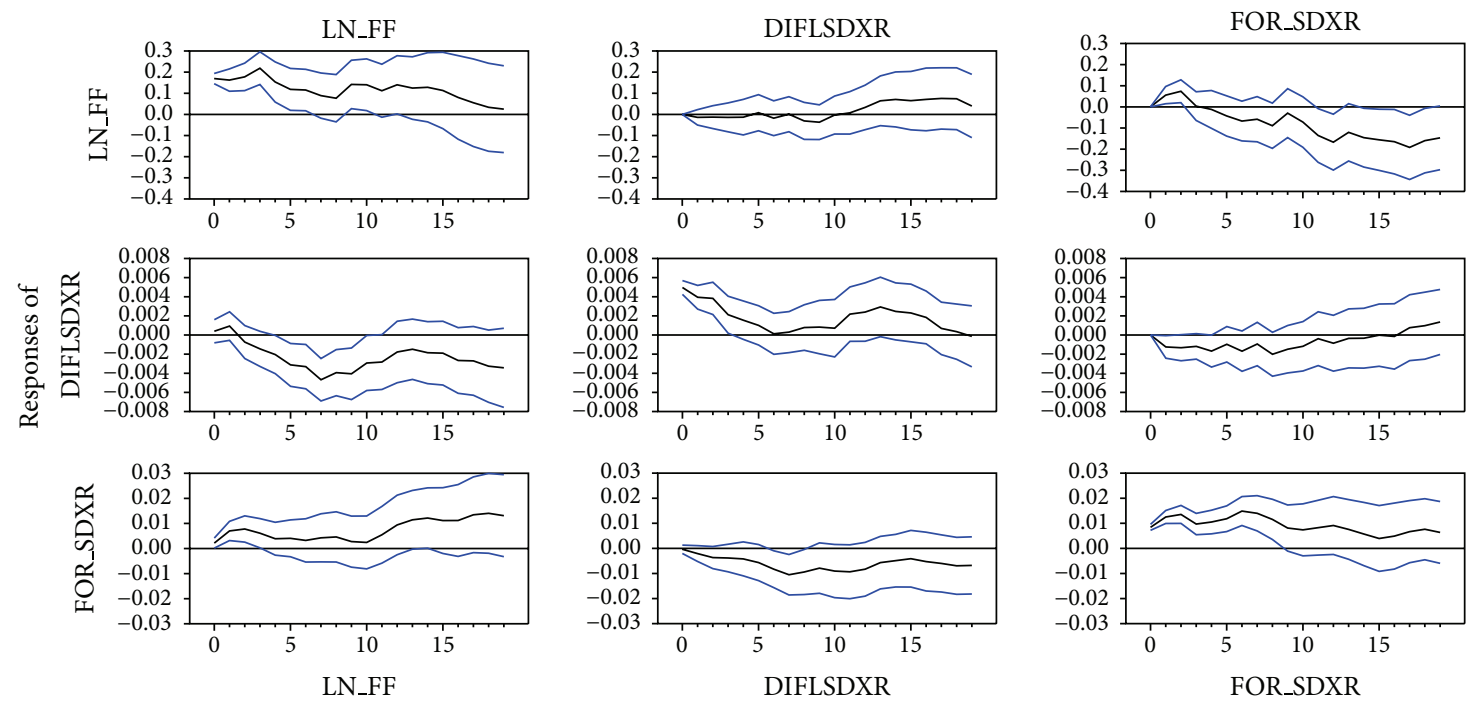

FIGURE 14

Impulse response functions $\operatorname{dif}(\log )$ model for San Francisco

2 SD bounds set by Monte Carlo integration
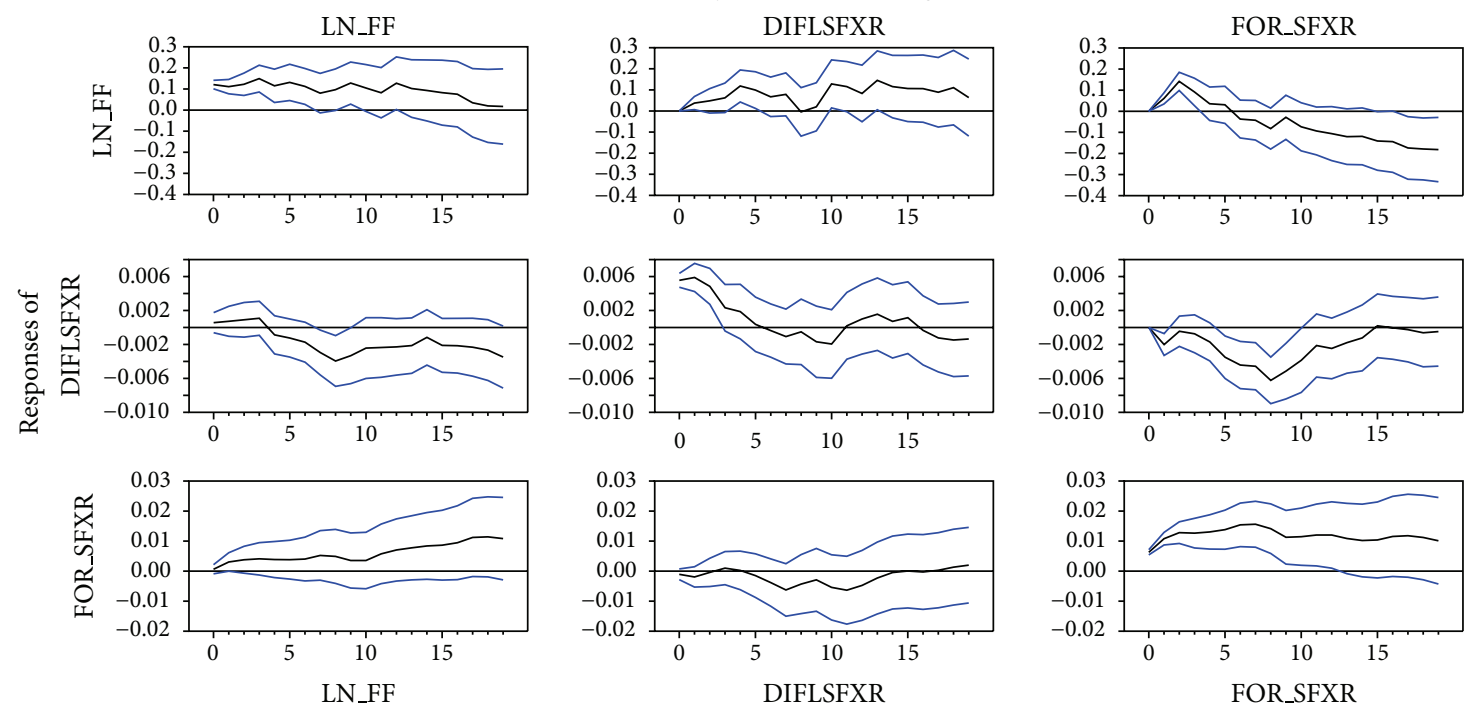

Figure 15

Table 3 shows the maximum effect and the month lag in which maximum effect is estimated to have taken place. The model estimated using the national data has effects that are significant at the 95\% level with the expected signs. The impulse response functions show negative effects of the foreclosure rate on the change in the log of the price index that are significant at the $95 \%$ level in 11 out of 13 metropolitan areas (and two positive and significant results-Dallas and Denver). The effect of the change in the log of the price index on the foreclosure rate is negative and significant at the $95 \%$ level in 10 out of 13 metropolitan areas (with one additional result that is negative and very close to being significant and two that are zero). The effects of the change in the log of the price index on itself and the foreclosure rate on itself both are positive and significant at the 95\% level in all 13 metropolitan areas. The effect of the federal funds rate on the log of the change in the housing price series is negative and significant at the $95 \%$ level in 11 out of 13 cases (with one significant result with a positive sign and one with no effect). And the effect of the federal funds rate on the foreclosure rate is positive and significant at the $95 \%$ level in 9 out of 13 cases (with three zero effects and one significant negative effect). In summary, of 84 impulse response results in Table 3, 73 are significant at the $95 \%$ level with the expected sign (and one is very close 


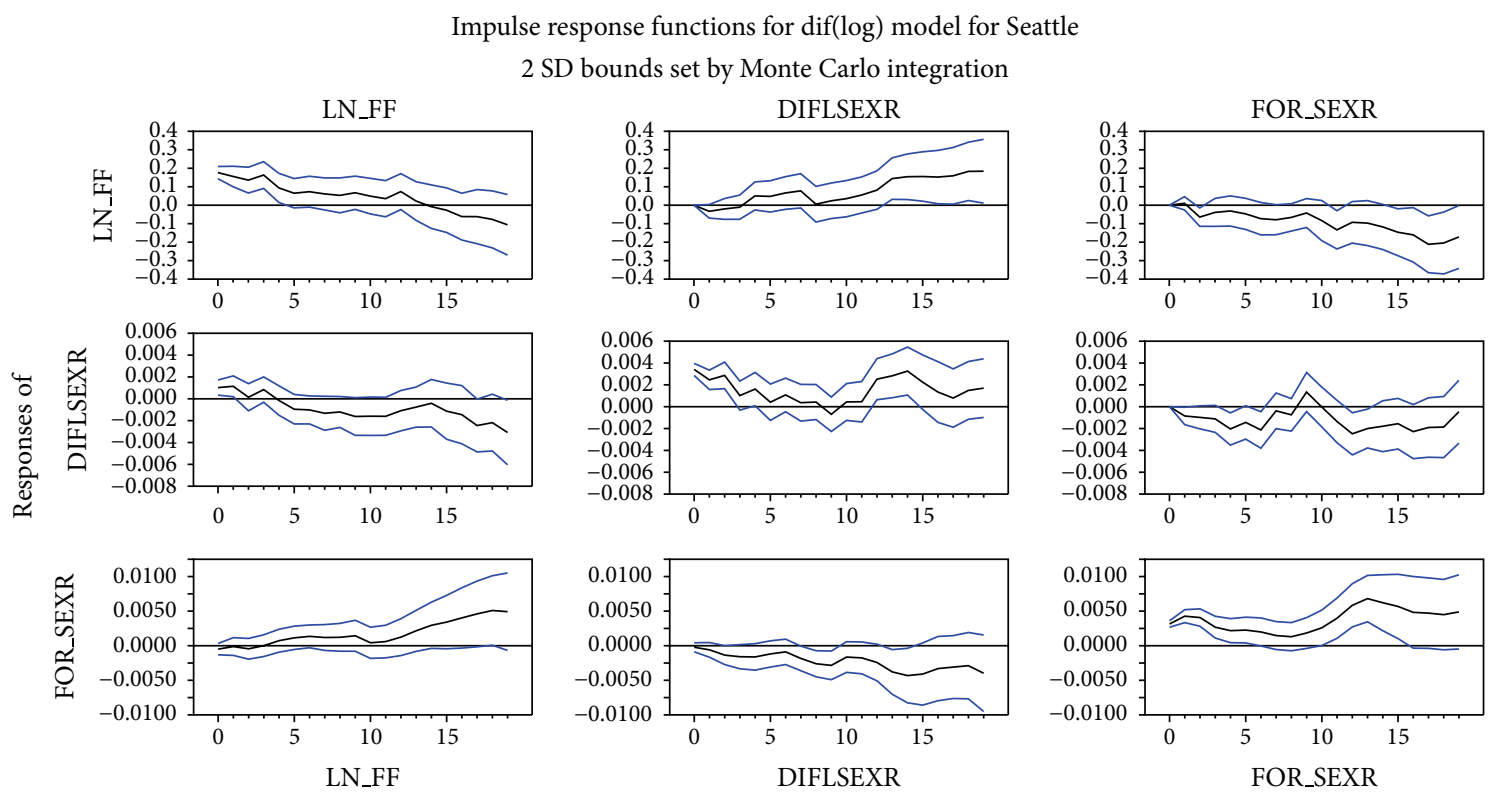

Figure 16

Impulse response functions for $\operatorname{dif}(\log )$ model for Washington DC

2 SD bounds set by Monte Carlo integration
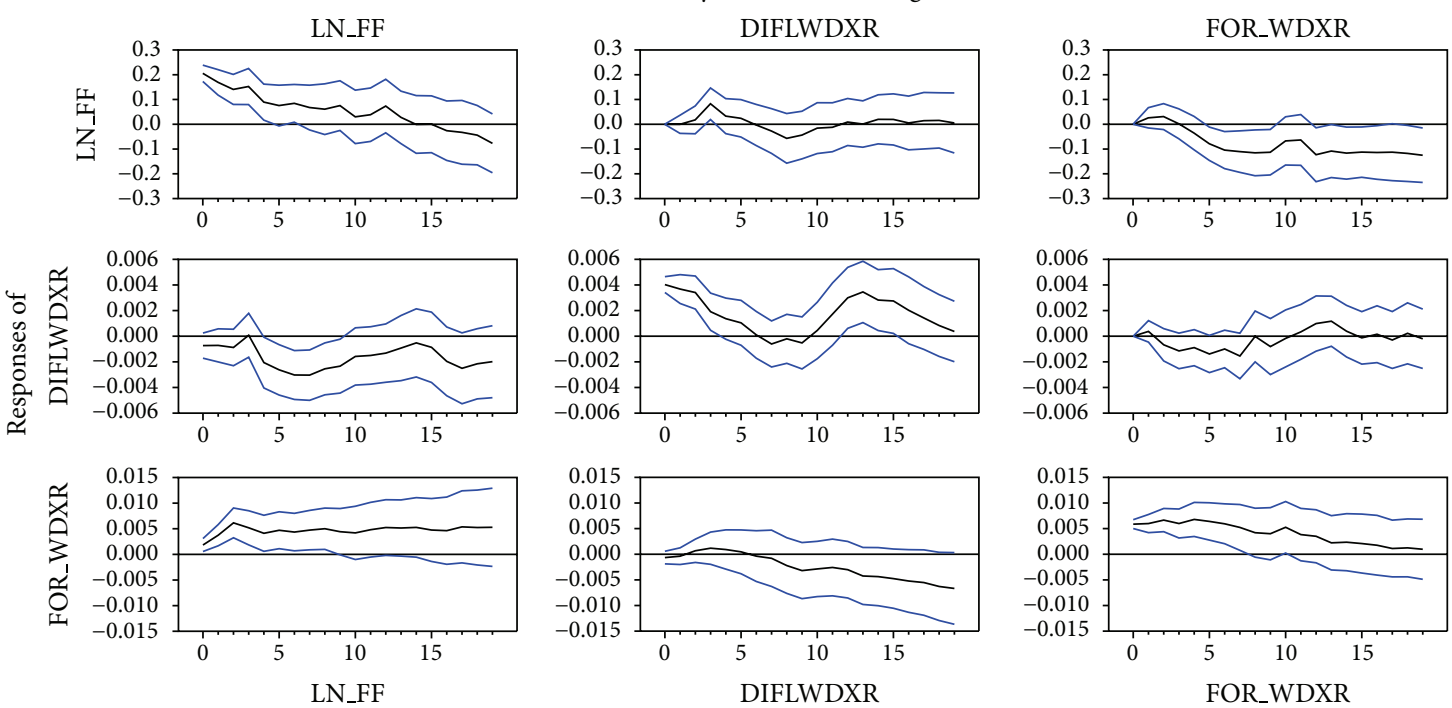

Figure 17

to $95 \%$ significance), 4 are significant not with the expected sign, and 7 show no effect. The expected sign is obtained in $88 \%$ of the cases.

The estimated models and Monte Carlo results suggest a basic story of the dynamics of the crisis in the housing market. An upward shock in the foreclosure rate triggers a decline in housing prices and a further increase in the foreclosure rate. The decline in housing prices generates further declines in housing prices and those declines in housing prices result in increases in foreclosures. In short, foreclosures and declines in housing prices result in both declines in housing prices (and loss of wealth) and in more foreclosures. Furthermore, an increase in the federal funds rate tended to generate more foreclosures and larger declines in housing prices.

This basic story is consistent with the hypothesis that the foreclosure crisis began with subprime mortgage loans. Subprime loans are loans to borrowers with relatively weak credentials. Zandi [35, page 38] shows that the subprime loans that were securitized in 2006 had an average loan-tovalue ratio of $95 \%$ and $90.6 \%$ had adjustable interest rates (87.1\% adjusted within three years or less). Adjustable-rate loans were used because subprime borrowers were charged an initial nonadjustable interest rate that was greater than the standard mortgage loans. As Gorton [49] suggests, these 
TABLE 3: Magnitude and Lag Length of Maximum Significant 95\% Shocks.

\begin{tabular}{|c|c|c|c|c|c|c|}
\hline $\begin{array}{l}\text { Metropolitan } \\
\text { Area } \\
\text { Exp. Sign } \\
\end{array}$ & $\begin{array}{c}\Delta \mathrm{LnP} \text { on } \\
\text { Foreclose } \\
\quad- \\
\end{array}$ & $\begin{array}{c}\text { Foreclose } \\
\text { on } \Delta \ln \mathrm{P} \\
- \\
\end{array}$ & $\begin{array}{c}\Delta \mathrm{LnP} \text { on } \\
\text { Itself } \\
+ \\
\end{array}$ & $\begin{array}{c}\text { Foreclose } \\
\text { on Itself } \\
+ \\
\end{array}$ & $\begin{array}{c}\text { LnFF } \\
\text { on } \Delta \operatorname{LnP} \\
- \\
\end{array}$ & $\begin{array}{c}\text { LnFF on } \\
\text { Foreclose } \\
+ \\
\end{array}$ \\
\hline Cleveland & & $\begin{array}{c}-0.0015 \\
(4)\end{array}$ & $\begin{array}{l}0.003(1,13) \\
-0.003(3) \\
\end{array}$ & $\begin{array}{c}0.0075 \\
(1)\end{array}$ & $\begin{array}{c}-0.0045 \\
(6)\end{array}$ & \\
\hline Dallas & $\begin{array}{c}-0.001 \\
(1)\end{array}$ & $\begin{array}{c}0.002 \\
(4) \\
\end{array}$ & $\begin{array}{c}0.002(1) \\
0.001(12) \\
\end{array}$ & $\begin{array}{c}0.004 \\
(6) \\
\end{array}$ & $\begin{array}{c}-0.001 \\
(6) \\
\end{array}$ & $\begin{array}{c}0.001 \\
(1) \\
\end{array}$ \\
\hline Denver & & $\begin{array}{c}0.0013 \\
(10)\end{array}$ & $\begin{array}{c}-0.0017(7) \\
0.002(12)\end{array}$ & $\begin{array}{c}0.017 \\
(1)\end{array}$ & $\begin{array}{c}0.001(2) \\
-0.001(17) \\
\end{array}$ & $\begin{array}{c}0.015 \\
(5)\end{array}$ \\
\hline Las Vegas & $\begin{array}{c}-0.025 \\
(7) \\
\end{array}$ & $\begin{array}{c}-0.002 \\
(2) \\
\end{array}$ & $\begin{array}{c}0.0055 \\
(2) \\
\end{array}$ & $\begin{array}{l}0.025 \\
(1,12) \\
\end{array}$ & $\begin{array}{c}-0.005 \\
(8) \\
\end{array}$ & $\begin{array}{c}0.030 \\
(14) \\
\end{array}$ \\
\hline Los Angeles & $\begin{array}{c}-0.017 \\
(7)\end{array}$ & $\begin{array}{c}-0.002 \\
(8)\end{array}$ & $\begin{array}{l}0.004 \\
(2,15) \\
\end{array}$ & $\begin{array}{c}0.008 \\
(7)\end{array}$ & $\begin{array}{c}-0.0035 \\
(9)\end{array}$ & \\
\hline Minneapolis & $\begin{array}{c}-0.001 \\
(2)\end{array}$ & $\begin{array}{c}-0.0045(3) \\
0.0025(12)\end{array}$ & $\begin{array}{l}0.005(2) \\
0.004(9)\end{array}$ & $\begin{array}{c}0.011 \\
(14) \\
\end{array}$ & $\begin{array}{c}0.0025 \\
(3)\end{array}$ & \\
\hline New York & $\begin{array}{c}-0.0009 \\
(14)\end{array}$ & $\begin{array}{c}-0.002 \\
(9)\end{array}$ & $\begin{array}{c}0.0023 \\
(2,13) \\
\end{array}$ & $\begin{array}{l}0.0008 \\
(2)\end{array}$ & $\begin{array}{c}-0.002 \\
(7,17) \\
\end{array}$ & $\begin{array}{c}0.004 \\
(2)\end{array}$ \\
\hline Phoenix & $\begin{array}{c}-0.025 \\
(15)\end{array}$ & $\begin{array}{c}-0.0045 \\
(8)\end{array}$ & $\begin{array}{c}0.004 \\
(3)\end{array}$ & $\begin{array}{l}0.020 \\
(6,13)\end{array}$ & $\begin{array}{c}-0.030 \\
(7)\end{array}$ & $\begin{array}{c}0.010 \\
(10)\end{array}$ \\
\hline Portland & $\begin{array}{c}-0.001(1) \\
-0.004(13)\end{array}$ & $\begin{array}{c}-0.004 \\
(7)\end{array}$ & $\begin{array}{c}0.0037 \\
(2)\end{array}$ & $\begin{array}{c}0.007 \\
(14)\end{array}$ & & $\begin{array}{c}-0.002 \\
(3)\end{array}$ \\
\hline San Diego & $\begin{array}{c}-0.011 \\
(7)\end{array}$ & $\begin{array}{c}-0.002 \\
(4)\end{array}$ & $\begin{array}{c}0.004 \\
(1)\end{array}$ & $\begin{array}{l}0.012 \\
(2,6)\end{array}$ & $\begin{array}{c}-0.005 \\
(7)\end{array}$ & $\begin{array}{c}0.014 \\
(18)\end{array}$ \\
\hline San Fran. & $\begin{array}{c}-0.006 \\
(8)\end{array}$ & $\begin{array}{c}-0.006 \\
(8)\end{array}$ & $\begin{array}{c}0.0055 \\
(1)\end{array}$ & $\begin{array}{c}0.015 \\
(7) \\
\end{array}$ & $\begin{array}{c}-0.004 \\
(8)\end{array}$ & $\begin{array}{c}0.002 \\
(1)\end{array}$ \\
\hline Seattle & $\begin{array}{c}-0.005 \\
(14)\end{array}$ & $\begin{array}{c}-0.003 \\
(12)\end{array}$ & $\begin{array}{c}0.0025 \\
(2,14) \\
\end{array}$ & $\begin{array}{c}0.0063 \\
(13)\end{array}$ & $\begin{array}{c}-0.002 \\
(9)\end{array}$ & $\begin{array}{c}0.005 \\
(18) \\
\end{array}$ \\
\hline Washington & $\begin{array}{c}-0.008 \\
(19)\end{array}$ & $\begin{array}{c}-0.002 \\
(7)\end{array}$ & $\begin{array}{c}0.0037 \\
(2,13)\end{array}$ & $\begin{array}{c}0.006 \\
(4)\end{array}$ & $\begin{array}{c}-0.0035 \\
(6)\end{array}$ & $\begin{array}{c}0.005 \\
(8)\end{array}$ \\
\hline U.S. & $\begin{array}{c}-0.0035 \\
(8)\end{array}$ & $\begin{array}{c}-0.002 \\
(8)\end{array}$ & $\begin{array}{c}0.0023 \\
(2,14)\end{array}$ & $\begin{array}{c}0.0025 \\
(12)\end{array}$ & $\begin{array}{c}-0.003 \\
(9)\end{array}$ & $\begin{array}{c}0.002 \\
(9)\end{array}$ \\
\hline
\end{tabular}

Effects close to significant $95 \%$ shocks in italics.

ARMs were designed to force the borrower to refinance into a lower-cost loan after two or three years-after the value of the house (and the borrower's equity stake) had increasedbecause the interest rate on the original loan would increase by a large amount at the time of adjustment. Lenders are safe only if house prices rise. The decline of house prices triggered the default of many of these loans. A chart provided by the Financial Crisis Inquiry Commission [13, page 217] illustrates the sharp increase in delinquencies of adjustablerate subprime loans that began in the middle of 2006, the point at which house prices stopped increasing and began to fall. This same chart shows that the increases of delinquencies of other types of mortgage loans lagged behind the increase of delinquencies of subprime ARMs. The Commission states [13, page 217] that "Serious delinquencies started earlier and were substantially higher among subprime adjustable-rate loans, compared to other types of loans." According to our results a shocks both in the change in housing prices and in foreclosures result in more foreclosures and larger declines in housing prices as well.

The impulse response function results in Table 3 that are contrary to expectations are few in number (four). The effect of foreclosures on the change in the log of the price index is positive for Dallas and Denver. As shown in Figure 6, Dallas had a relatively small increase in housing prices and suffered virtually no subsequent housing price decline. These outcomes perhaps can be attributed to Texas mortgage lending laws that are different from those in other states and are designed to prevent some of the worst mortgage lending abuses. For example, both loans with negative amortization and high-cost loans with balloon payments are prohibited. Mortgage brokers that are licensed must conform to strict disclosure rules and can face fines and imprisonment for providing false information to borrowers. Denver also experienced a relatively modest increase and subsequent decline in housing prices, but Figure 7 shows a large decline in the foreclosure rate after the housing price peak. This decline can be explained by the change in the Colorado foreclosure law in 2008, that extended the time between the commencement of the foreclosure process and the foreclosure sale from 60 to 125 days. Other provisions prevented foreclosure sales in March and April of 2008 and delayed foreclosure filings. The effect of the federal funds rate on the change in the log of housing prices was positive in Minneapolis perhaps because the largest decline in housing prices took place during the last half of 2008 and early 2009, when the Fed 
was dropping the federal funds rate dramatically. The effect of the federal funds rate on foreclosures in Portland and Oregon was negative perhaps because the foreclosure rate spiked upwards in late 2010-after the federal funds rate had been reduced to its lowest level. A possible explanation is that Oregon experienced the recession later than did most states. These specific outcomes can be topics for further research.

\section{Conclusion}

This study makes use of monthly time-series data on housing prices and foreclosure rates at the metropolitan level in the period from 2000(1) to 2011(3) to estimate models of the interactions between these two endogenous variables, contingent on the federal funds rate. The results are that, at the level of the metropolitan area, increases in the foreclosure rate lead to declines in house prices (with a lag) and further increases in the foreclosure rate. A larger decline in housing prices results in an increase in foreclosures and an even larger decline in housing prices. Only the cross-section study by Mian et al. [26] tested for and found a negative (contemporaneous) effect of foreclosures on house prices at the level of the metropolitan area (CBSA), but it did not test for the effect of housing prices on foreclosures due to the research design of their study. The estimated lags in the effects vary by metropolitan area. Tests of the model at the national level find that all four of these effects are statistically significant with the expected signs.

The basic findings of the study are consistent with the view that the financial crisis of the late 2000-2010 decade originated in the portion of the home mortgage market that was dominated by especially risky subprime home loans that seem almost designed to fail unless housing prices continued to rise. The sharp increases in delinquencies and subsequent foreclosures on these loans set off declines in house prices (and loss of wealth) and further increases in foreclosures, which produced huge losses in the values of the mortgagebacked securities and other assets that were based on these loans. The existence of what appear to be strong dynamic negative externalities between housing prices and foreclosure rates suggests stronger policy responses than have been attempted thus far.

\section{Conflict of Interests}

There exists no financial interest (direct or indirect) with any commercial entity mentioned that might lead to a conflict of interests for any of the authors.

\section{References}

[1] D. R. Capozza and R. Van Order, "The great surge in mortgage defaults 2006-2009: the comparative roles of economic conditions, underwriting and moral hazard," Journal of Housing Economics, vol. 20, no. 2, pp. 141-151, 2011.

[2] J. F. McDonald and H. H. Stokes, "Monetary policy and the housing bubble," Journal of Real Estate Finance and Economics, vol. 46, pp. 437-451, 2013.
[3] M. Jarociński and F. R. Smets, "House prices and the stance of monetary policy," Federal Reserve Bank of St. Louis Review, vol. 90, no. 4, pp. 339-365, 2008.

[4] C. Vargas-Silva, "Monetary policy and the US housing market: a VAR analysis imposing sign restrictions," Journal of Macroeconomics, vol. 30, no. 3, pp. 977-990, 2008.

[5] T. Clauretie and G. Sirmans, Real Estate Finance, Cengage, Mason, Ohio, USA, 6th edition, 2010.

[6] R. Green, A. B. Sanders, and S. Wachter, "Special issue on subprime mortgage lending," Journal of Housing Economics, vol. 17, no. 4, p. 253, 2008.

[7] A. B. Sanders and R. Van Order, "Introduction to the special issue on housing and the credit crunch," Journal of Housing Economics, vol. 20, no. 2, pp. 66-67, 2011.

[8] K. Vandell, "How ruthless is mortgage default? A review and synthesis of the evidence," Journal of Housing Research, vol. 62, pp. 245-264, 1995.

[9] M. LaCour-Little, "Mortgage termination risk: a review of the recent literature," Journal of Real Estate Literature, vol. 16, no. 3, pp. 297-326, 2008.

[10] Y. Deng, J. M. Quigley, and R. Van Order, "Mortgage terminations, heterogeneity and the exercise of mortgage options," Econometrica, vol. 68, no. 2, pp. 275-307, 2000.

[11] C. L. Foote, K. Gerardi, L. Goette, and P. S. Willen, "Just the facts: an initial analysis of subprime's role in the housing crisis," Journal of Housing Economics, vol. 17, no. 4, pp. 291-305, 2008.

[12] Y. Deng, A. D. Pavlov, and L. Yang, "Spatial heterogeneity in mortgage terminations by refinance, sale and default," Real Estate Economics, vol. 33, no. 4, pp. 739-764, 2005.

[13] Financial Crisis Inquiry Commission, The Financial Crisis Inquiry Report, Public Affairs, Perseus Books, New York, NY, USA, 2011.

[14] C. deRitis, C. Kuo, and Y. Liang, "Payment shock and mortgage performance," Journal of Housing Economics, vol. 19, no. 4, pp. 295-314, 2010.

[15] W. R. Archer and B. C. Smith, "Residential mortgage default: the roles of house price volatility, euphoria and the borrower's put option," Journal of Real Estate Finance and Economics, vol. 46, pp. 355-378, 2013.

[16] T. Clauretie and T. Herzog, "The effect of state foreclosure laws on loan losses: evidence from the mortgage insurance industry," Journal of Money, Credit, and Banking, vol. 22, pp. 221-233, 1990.

[17] J. Shilling, J. Benjamin, and C. F. Sirmans, "Estimating net realizable value for distressed real estate," Journal of Real Estate Research, vol. 5, pp. 129-139, 1990.

[18] F. Forgey, R. Rutherford, and M. VanBuskirk, "Effect of foreclosure status on residential selling price," Journal of Real Estate Research, vol. 9, pp. 313-318, 1994.

[19] W. Hardin and M. Wolverton, "The relationship between foreclosure status and apartment price," Journal of Real Estate Research, vol. 12, pp. 101-109, 1996.

[20] T. M. Springer, "Single-family housing transactions: seller motivations, price, and marketing time," Journal of Real Estate Finance and Economics, vol. 13, no. 3, pp. 237-254, 1996.

[21] T. Carroll, T. Clauretie, and H. Neill, "Effect of foreclosure status on residential selling price: comment," Journal of Real Estate Research, vol. 13, pp. 95-102, 1997.

[22] A. Pennington-Cross, "The value of foreclosed property," Journal of Real Estate Research, vol. 28, no. 2, pp. 193-214, 2006. 
[23] T. M. Clauretie and N. Daneshvary, "Estimating the house foreclosure discount corrected for spatial price interdependence and endogeneity of marketing time," Real Estate Economics, vol. 37, no. 1, pp. 43-67, 2009.

[24] J. Y. Campbell, S. Giglio, and P. Pathak, "Forced sales and house prices," American Economic Review, vol. 101, no. 5, pp. 2108-2131, 2011.

[25] A. C. Goodman and B. C. Smith, "Residential mortgage default: theory works and so does policy," Journal of Housing Economics, vol. 19, no. 4, pp. 280-294, 2010.

[26] A. Mian, A. Sufi, and F. Trebbi, "Foreclosures, house prices, and the real economy," Working Paper 16685, National Bureau of Economic Research, 2011.

[27] N. Daneshvary, T. M. Clauretie, and A. Kader, "Short-term ownprice and spillover effects of distressed residential properties: the case of a housing crash," Journal of Real Estate Research, vol. 33, no. 2, pp. 179-208, 2011.

[28] D. Immergluck and G. Smith, "The external costs of foreclosure: the impact of single-family mortgage foreclosures on property values," Housing Policy Debate, vol. 17, no. 1, pp. 57-79, 2006.

[29] Z. Lin, E. Rosenblatt, and V. W. Yao, "Spillover effects of foreclosures on neighborhood property values," Journal of Real Estate Finance and Economics, vol. 38, no. 4, pp. 387-407, 2009.

[30] J. Schuetz, V. Been, and I. G. Ellen, "Neighborhood effects of concentrated mortgage foreclosures," Journal of Housing Economics, vol. 17, no. 4, pp. 306-319, 2008.

[31] J. P. Harding, E. Rosenblatt, and V. W. Yao, "The contagion effect of foreclosed properties," Journal of Urban Economics, vol. 66, no. 3, pp. 164-178, 2009.

[32] T. Leonard and J. C. Murdoch, "The neighborhood effects of foreclosure," Journal of Geographical Systems, vol. 11, no. 4, pp. 317-332, 2009.

[33] W. H. Rogers and W. Winter, "The impact of foreclosures on neighboring housing sales," Journal of Real Estate Research, vol. 31, no. 4, pp. 455-479, 2009.

[34] R. Shiller, The Subprime Solution, Princeton University Press, Princeton, NJ, USA, 2009.

[35] M. Zandi, Financial Shock, FT Press, Upper Saddle River, NJ, USA, 2009.

[36] J. Hamilton, "On testing for self-fulfilling speculative price bubbles," International Economic Review, vol. 27, pp. 545-552, 1986.

[37] V. Mikhed and P. Zemčík, "Testing for bubbles in housing markets: a panel data approach," Journal of Real Estate Finance and Economics, vol. 38, no. 4, pp. 366-386, 2009.

[38] A. C. Ghent and M. Kudlyak, "Recourse and residential mortgage default: evidence from US states," Review of Financial Studies, vol. 24, no. 9, pp. 3139-3186, 2011.

[39] A. Pennington-Cross, "The duration of foreclosures in the subprime mortgage market: a competing risks model with mixing," Journal of Real Estate Finance and Economics, vol. 40, no. 2, pp. 109-129, 2010.

[40] C. Granger, "Investigating causal relations by econometric models and cross-spectral models," Econometrica, vol. 37, pp. 424-438, 1969.

[41] W. Greene, Econometric Analysis, Pearson/Prentice Hall, Upper Saddle River, NJ, USA, 6th edition, 2008.

[42] C. Sims, "Macroeconomics and reality," Econometrica, vol. 48, pp. 1-49, 1980.
[43] A. Zellner and F. Palm, "Time series analysis and simultaneous equation econometric models," Journal of Econometrics, vol. 2, no. 1, pp. 17-54, 1974.

[44] G. Box, G. Jenkins, and G. Reinsel, Time Series Analysis: Forecasting and Control, John Wiley \& Sons, Hoboken, NJ, USA, 4th edition, 2008.

[45] T. Doan, RatS USer'S Manual: VerSion 8.0, Evanston, Ill, USA, 2010.

[46] H. Stokes, Specifying and Diagnostically Testing Econometric Models, Quorum Books, New York, NY, USA, 3rd edition, 2011.

[47] T. Doan, Rats Reference Manual: Version 8.0, Evanston, Ill, USA, 2010.

[48] W. Enders, Applied Econometric Time Series, John Wiley \& Sons, Hoboken, NJ, USA, 2nd edition, 2004.

[49] G. Gorton, Slapped by the Invisible Hand, Oxford University Press, New York, NY, USA, 2010. 


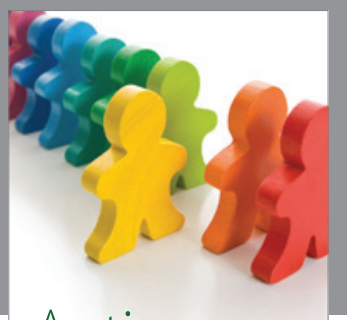

Autism

Research and Treatment
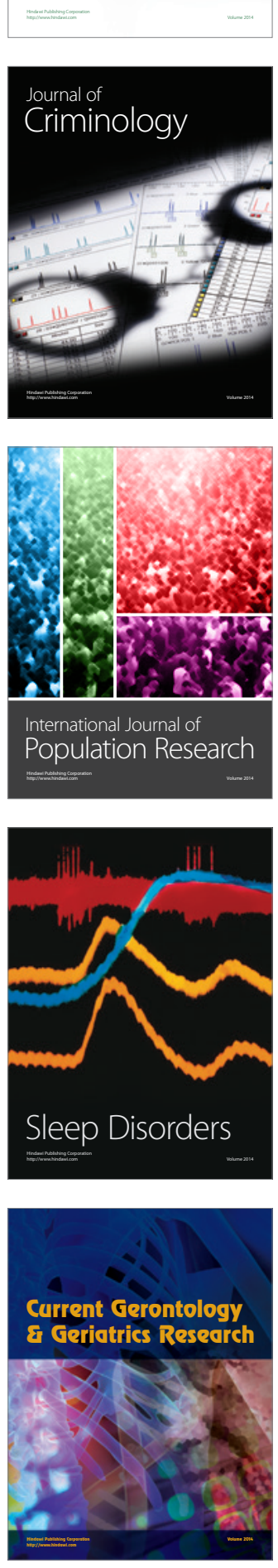
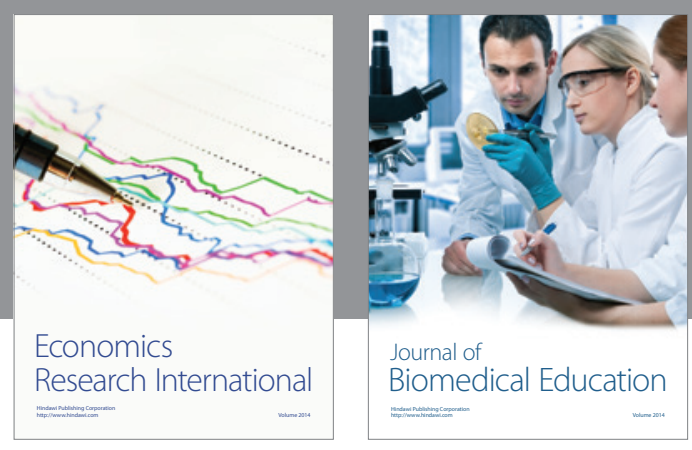

Journal of

Biomedical Education

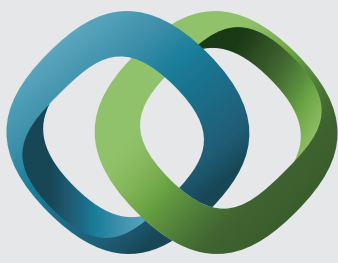

\section{Hindawi}

Submit your manuscripts at

http://www.hindawi.com
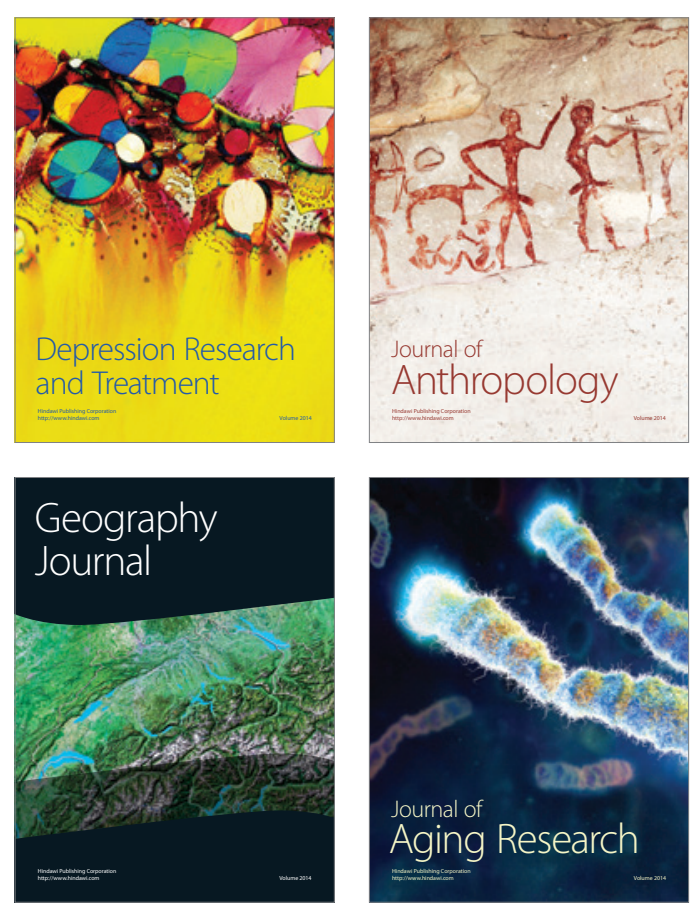

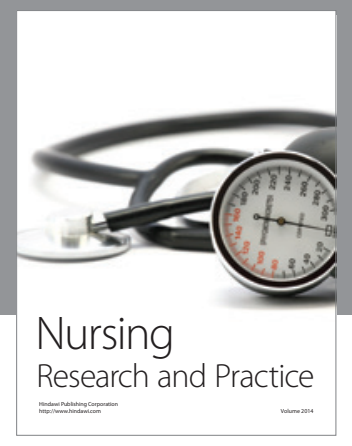

Nursing

Research and Practice

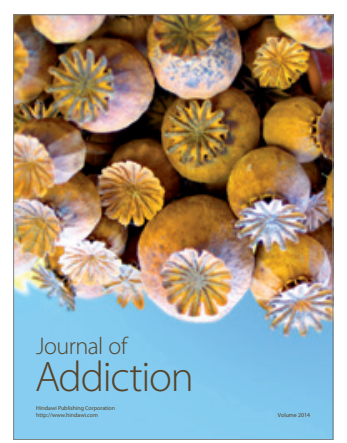

Child Development

Research

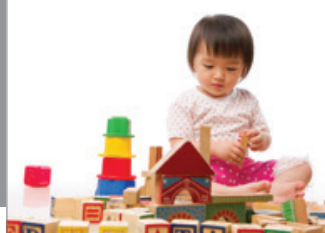

迥
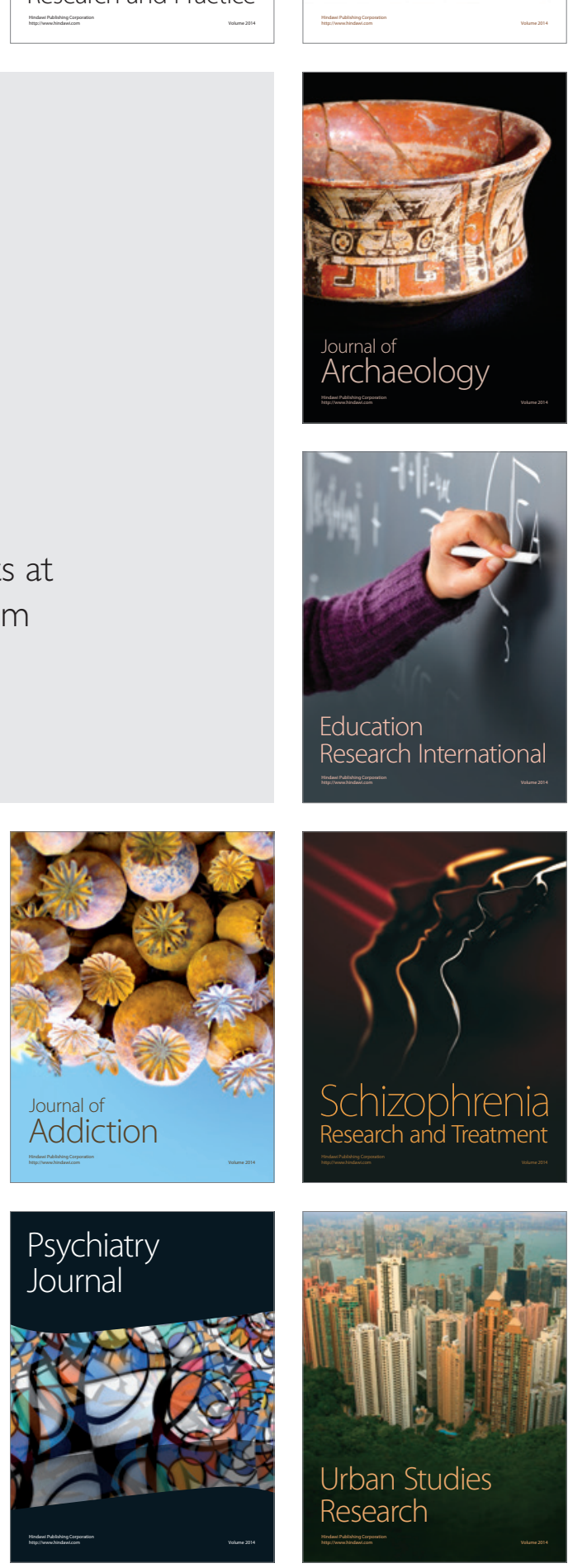